\title{
Waiver of Rights in Police Interrogations: Miranda in the Lower Courts
}

Before Miranda v. Arizona ${ }^{1}$ a patchwork of exclusionary rules governed the admissibility at trial of statements obtained from a suspect during custodial interrogation. The fundamental standard for review of coerced confession cases was "voluntariness," as determined by an examination of the "totality of circumstances" surrounding a confession. ${ }^{2}$ This standard was supplemented by the exclusionary rules of Massiah v. United States ${ }^{3}$ and Escobedo v. Illinois, ${ }^{4}$ and by the

1384 U.S. 496 (1966). The Court's opinion covered four separate cases, Miranda $v_{4}$ Arizona, Vignera v. New York, California v. Stewart, and Westover t. United States. See also United States v. Westover, 342 F.2d 684 (9th Gir. 1965); State v. Miranda, 98 Atiz. 18, 401 P.2d 721 (1965); People v. Stewart, 62 Cal. 2d 571, 43 Cal. Rptr. 201, 400 P.2d 97 (1965); People v. Vignera, 15 N.Y.2d 970, 207 N.E.2d 527, 259 N.Y.S.2d 19 (1964), aff'g without opinion, 21 App. Div. 2d 752, 252 N.Y.S.2d 19 (1964). In a later dećision, Johnson v. New Jersey, 384 U.S. 719 (1966), the Court held that the rules established in Miranda were only to be applied to cases tried after June 13, 1966, the date of the Court's decision in that case.

2 Haynes v. Washington, 373 U.S. 503, 514-15 (1963). Under the due process "totality of circumstances" test the court's considered such factors as (1) physical abuse, Lee v. Mississippi, 332 U.S. 742 (1948); Brown v. Mississippi, 297 U.S. 278 (1936); (2) threats, Lynumn v. Illinois, 372 U.S. 528 (1963) (to loše custōdy of children); Payne v. Arkansas, 356 U.S. 560 (1958) (of mob violence); Rogers v. Richmond, 365 U.S. 534 (1961) (to take wife into custody); (3) extensive questioning, Gulombe v. Connecticut, 367 U.S. 568 (1961) (121/2 hours of questioning over 5 days); Johnson v. Pennsylvania, 340 U.S. 881 (1950) (6 hours of questioning over 5 days); Turner v. Pennsylvania, 398 U.S. 62 (1949) (23 hours of questioning over a period of 5 days); (4) incommunicado detention, Davis v. North Garolina, 384 U.S. 737 (1966) (incommunicado for 16 days); Haynes v. Washington, 373 U.S. 503 (1963) (incommunicado for 16 hours and refused access to wife or counsel); Malinsky v. New York, 324 U.S. 401 (1945) (not allowed to see friends); (5) denial of the right to consult with counsel, Fay v. Noia, 372 U.S. 391 (1963); Cicenia v. Lagay, 357 U.S. 504 (1958); Grooker v. Galifornia, 357 U.S. 433 (1958); (6) individual deficiencies and talents of the accused, Golumbe v. Connecticut, 367 U.S. 568 (1969) (lack of education); Spano v. New York, 360 U.S. 315 (1959) (emotional instability); Crooker v. California, 357 U.S. 433 (1958) (law school training); Fikes v. Alabama, 352 U.S. 191 (1957) (feeblemindedness); (7) status of the accused, Jackson v. Denno, 378 U.S. 368 (1964) (sickness); Townsend v. Sain; 372 U.S. 293 (1963) (drugged); (8) youth, Gallegos v. Colorado, 370 U.S. 49 (1962); Haley v. Ohio, 332 U.S. 596 (1947). See generally, Developments in the Law-Confessions, 79 HARv. L. REv. 935, 961-83 (1966) [hereinafter cited as Developments].

3377 U.S. 201 (1964). On the basis of the sixth amendment, the Court in Massiah held that incriminating statements extracted by fedetal officers from an indicted person in the absence of previously retained counsel were inadmissible in evidence. The sixth amendment right to counsel had previously been held binding on the states through the fourteenth amendment in Gideon v. Wainwright, 372 U.S. 335 (1963). See McLeod v. Ohio, 381 U.S. 356 (1965). 
$M c N a b b-M a l l o r y$ rule against unnecessary delays prior to arraignment in federal confession cases. ${ }^{5}$ In Miranda the Court superimposed additional protections on the due process "voluntariness" standard by firmly establishing the fifth amendment privilege against compulsory self-incrimination ${ }^{6}$ as the legal justification for review of the admissibility of a suspect's in-custody statements. ${ }^{7}$ The Court's extension of the fifth amendment privilege to police interrogation ${ }^{8}$ an extension previously thought to be impeded by linguistic and historical barriers ${ }^{9}$ - signaled an attempt to restrike the pretrial balance

4378 U.S. 478 (1964). In Escobedo the majority relied on the sixth amendment to reverse a conviction by finding that police interrogation prior to indictment was a "critical stage" at which the right to counsel attached. The "critical stage" concept had previously been expanded by the Court in Hamilton v. Alabama, 368 U.S. 52 (1961) (arraignment) and in White v. Maryland, 373 U.S. 59 (1963) (preliminary hearings).

5 McNabb v. United States, 318 U.S. 332 (1943); Mallory v. United States, 354 U.S. 449 (1957). This exclusionary rule is embodied in the Federal Rules of Criminal Procedure. See FED. R. CRIM. P. 5(a). The effect of the Omnibus Crime Act of 1968 on the $M c N a b b$ Mallory rule is unclear. See 18 U.S.C. \$ 3501(c) (Supp. I, 1969).

6 "No person ... shall be compelled in any criminal case to be a witness against himself." U.S. Const. amend. V. The privilege was made applicable to the states by virtue of the due process clause of the fourteenth amendment in Malloy v. Hogan, 378 U.S. 1 (1964), where the Court held that state courts must employ the same standards as federal courts in applying the fifth amendment protection. Id. at 10-11.

7384 U.S. at 460-I. The Court in Bram v. United States, I68 U.S. 532 (1897), stated, in dictum, that:

In criminal trials, in the courts of the United States, wherever a question arises whether a confession is incompetent because not voluntary, the issue is controlled by that portion of the Fifth Amendment to the Constitution of the United States, commanding that no person "shall be compelled in any criminal case to be a witness against himself." Id. at 542.

Its decision, however, rested on the "voluntariness" test of the established "confessions doctrine." Until Miranda both federal decisions and state authorities were in conflict as to the constitutional basis for review of coerced confession cases. See 8 WIGMORE, Evidence § 2252 n.27 (McNaughton rev. ed. 1961) [hereinafter cited as WigMoRE] and cases cited therein.

8 Miranda enlarged the protection of the privilege to guard not only against "Iegal compulsion"-usually in the form of contempt proceedings-but also against the "informal compulsion" inherent in custodial surroundings. 384 U.S. at 461 . It is worth noting that "legal compulsion" can take other forms besides contempt proceedings. In Garrity v. New Jersey, 385 U.S. 493 (1967), the Court held that the fifth amendment privilege barred the use in subsequent criminal proceedings of testimony elicited from policemen at an administrative hearing by a threat of discharge. In Spevack v. Klein, 385 U.S. 511 (1967), five members of the Court held that disbarment is a "penalty" within the protection of the privilege, so that an attorney named in disbarment proceedings could claim the privilege against a subpoena ordering him to produce incriminating records without being disbarred for his refusal to comply.

- See 8 WIGMORE $\$ \S 2266,2252$. The rule giving a privilege against testimonial selfincrimination had a history, scope and development distinct from the rule excluding coerced confessions, id. at \$ 2266; Morgan, The Privilege Against Self-Incrimination, 34 MnN. L. REv. 1, 18 (1949), and at common law did not apply to police interrogations, 8 Wigmore at $\$ 2252$. Until Miranda, the privilege covered only disclosures made under legal compulsion. Id. at $\S 2266$. Since police have no legal authority to compel statements 
between state and accused by imposing exacting constitutional requirements for all custodial interrogations. ${ }^{10}$

of any kind, there was no legal obligation to which a privilege in the technical sense could apply; hence, it made little sense to say that an individual would be excused from the legal consequences of contumacy where there were no legal consequences of contumacy. Id. \$ 2252 n.27. Moreover, the limitations on confessions developed under the "totality of circumstances" test under the due process clause of the fourteenth amendment were thought by many to provide an adequate constitutional framework for the review of coerced confession cases. See $i d$. at $\$ 2266$; 384 U.S. at 503 (Clark, J., dissenting); id. at 506, 508 (Harlan, J., joined by White and Stewart, JJ., dissenting).

But the confessions doctrine as it applied to state criminal confessions cases did not extend in all jurisdictions to exclude evidence of coerced admissions (as opposed to confessions, admitting all elements of the crime), nor did it exclude evidence of silence in the face of accusation. 8 WIGMORE $\$ 2252$ n.27. Although there is no legal obligation to disclose to police, before Miranda there was the danger that the police could successfully misrepresent that there was such a legal obligation. Id. at \$ 2252. Even in the absence of such deception, suspects might assume that there were legal (or extra-legal) sanctions for contumacy. P. Devlin, The Criminal Prosecution in England 32 (1960). Thus the linguistic argument based on the technical meaning of the word "privilege" has been criticized as being "casuistic," Traynor, The Devils of Due Process in Criminal Detection, Detention, and Trial, 39 U. CHI. L. REv. 657, 674 (1966) and "a quibble," McNaughton, The Privilege Against Self Incrimination: Its Constitutional Affection, Raison d'Etre and Miscellaneous Implications, in Police Power ANd Indrvidual Freedom 228, 237 (Sowle ed. 1962). Furthermore, the safeguards against intimidation and trickery afforded by publicity, rules of trial procedure, the presence of an impartial judicial officer, and representation by counsel are wholly lacking in custodial interrogation. As a practical matter, there may be extra-legal police methods for compelling disclosure far more severe than the legal sanctions threatened or employed by a court. 8 WrgMORE $\S 2252$ n.27.

Nor is it clear that the Miranda extension "has no significant support in the history of the privilege. ..." (White, J., dissenting in Miranda, 384 U.S. at 526). It has been argued that the American police, in interrogating an accused, assume a function which has always been within the spirit of the privilege, Kamisar, $A$ Dissent from the Miranda Dissents: Some Comments on the "New" Fifth Amendment and the Old "Voluntariness" Test, 65 MICk. L. REv. 59, 66 (1965) [hereinafter cited as Kamisar], and which is exactly the function of the old English committing magistrate, before whom the privilege did apply. Morgan, 34 MinN. L. REv. at 22-7, 28 n.49. Since at the time of the Constitutional Convention an accused was incompetent to testify at his own trial under the party interest rule, the protection of the accused at criminal trial could not have been the object of the framers of the fifth amendment if they intended the provision to be other than a confirmation of the common law. Corwin, The Supreme Court's Construction of the Self-Incrimination Clause, 29 Mich. L. Rev. 1-12 (1930); L. Levy, ORigins of the Fifth AMENdment 407 (1968). In light of the colonial experience with oppressive questioning of suspects by representatives of the English crown, it may be that the drafters of the provision had chiefly in mind the protection of the accused (and of the suspect not yet charged) from pre-trial questioning. Mayers, The Federal Witness' Privilege Against Self-Incrimination: Constitutional or Common Law? 4 AM. J. OF LFGAL HIst. 107, $114 \mathrm{n} .20$ (1960). In addition, the expansive readings accorded to the constitutional privilege in the past have been urged as precedent for its recent extension to police interrogations.

The linguistic and historical barriers, whatever they were, which lay in the path

of Miranda's application of the privilege to custodial questioning were considerably

less formidable than those surmounted when the privilege was applied to legislative investigations and civil proceedings. Kamisar at 64-5.

10 Both "custody" and "interrogation" are requisites for the application of the Miranda waiver rules. An analysis of the myriad problems surrounding the questions of "custody" 
The four-fold warnings of legal rights required by Miranda ${ }^{11}$ were designed to provide a suspect with an adequate basis for deciding whether to remain silent or to request counsel. Several recent studies, however, have challenged the Court's assumption that the required warnings can provide concrete "assurance of real understanding and intelligent exercise of the privilege [of silence]."12 If the Miranda warnings are ineffective, as these studies suggest, ${ }^{13}$ it would seem that the primary bulwark against the erosion of constitutional rights in custodiąl interrogations ${ }^{14}$ must be furnished by Miranda's second principal requirement - that the suspect "voluntarily, knowingly and intelligently" waive his rights prior to any interrogation. ${ }^{15}$ As the practice of giving warnings becomes standardized among law enforcement officers, ${ }^{16}$ the aḍmisşibịlity of challenged confessions will hinge in-

and "interrogation" is beyond the scope of this comment. For a critical examination of these issues see Graham, What is "Custodial Interrogation?": California's Anticipatory Application of Miranda v. Arizona, 14 U.C.L.A.L. Rev, 59 (1966).

11 An accused must be warned in "clear and unequivocal terms" that he "has the right to remain silent, that anything he says can be used against him in a court of law, that he has the right to the presence of an attorney, and that if he cannot afford an attorney one will be appointed for him prior to any questioning if he so desires." 384 U.S. at 467-8 and at 479 . The Miranda opinion itself is not clear whether police are required to give a warning that any statements made by the accused will be used against him. Compare id. at 469 ("can and will") with id. at 479 ("can") and id. at 444 ("may"). In Graft v. United States, 403 F.2d 360 (9th Cir. 1968), the Ninth Circuit, rejecting the defendant's argument that the warnings he received were inadequate because he was not admonished that any information elicited from him "will be" used against him, held that the accused was sufficiently apprised of his Miranda rights by a warning that any statements "could be" used against him. Id. at 364 .

12384 U.S. at 469. See Griffiths \&. Ayres, A Postscript to the Miranda Project: Interrogation of Draft Protestors, 77 YALE L.J. 300, 318 (1967); Project, Interrogations in New Haven: The Impact of Miranda, 76 YALE L.J. 1519, 1614 (1967); Medalie, Zeitz \& Alexander, Custodial Interrogation in Our Nation's Capital: The Attempt to Implement Miranda, 66 MICH. L. REv. $13 \dot{4} 7$ (1968).

13 Instead of strengthening the position of the suspect in a confrontation with police interrogators, the Miranda warnings when given by police may in fact operate to lessen the suspect's resistance to persuasion and help to induce hị confession. Driver, Confessions and the Social Psychology of Coercion, 82 HARv. L. REv. 42, 61 (1968) states: "But another reason for the association between warnings and successful interrogation is the experimental finding that 'one dissonance-reducing mechanism is to react to a forewarning that one's belief's will be attacked with a preparatory reduction in the belief level.' "'

14 It is worth noting that "custodial interrogations" are by no means confined to the formal setting of the station house. Se note 10 supra.

15384 U.S. at 444,479 . The Court is not entirely clear whether Miranda permits police to administer warnings and then to interrogate a suspect without first obtaining a waiver, so long as a waiver is obtained before the suspect makes stațements which are sought to be introduced in evidence at trial. See text accompanying notes 70-5 infra.

16 At the present time the practice of giving adequate warnings of legal rights appears to be far from universal. See Project, Interrogations in New Haven: The Impact of Miranda, 76 YALE L.J. 1519, 1550 (1967) (police station obseryers reported that full Miranda warnings were given to only 25 of 118 suspects (21\%) questioned by police); Medalie, Zeitz \&: 
creasingly upon the courts' determination that an accused made a valid waiver of his Miranda rights.

After outlining brielly the contrast between the Miranda waiver rules and the rules for waiver of the fifth amendment privilege in other proceedings, this comment will examine the lower courts' response to Miranda's mandate that a "voluntary, knowing and intelligent" waiver is a prerequisite to admissibility. The troublesome waiver issues which have emerged from several factual situations will be investigated to determine if the lower courts are indeed striking a new balance between the state's need for confessions and the suspect's interest in fair and decent treatment in custodial interrogations.

\section{Fifth Amendment Waiver in Other Proceedings}

"Waiver" is classically defined as "an intentional relinquishment or abandonment of a known right or privilege."17 The standards for waiver of a constitutional right are inseparable from the definition of the right, ${ }^{18}$ although the Court has often spoken of a monolithic concept of waiver, applicable to all constitutional rights. ${ }^{\text {ig }}$ For example, rigorous requirements must be met to waive the sixth amendment right to representation by counsel at trial, ${ }^{20}$ but less severe stan-

Alexander, Custodial Police Interrogation in Our Nation's Capital: The Attempt to Implement Miranda, $66 \mathrm{Mrch}$. I. REv. 1347, 1365-6 n.67 (1968) (of 41 post-Miranda suspects interrogated by police, only 11 (27\%) reported that they had received all four Miranda warnings). However, the practice of reading warnings from a "Miranda card" would appear to foreshadow the elimination of most issues of the adequacy of warnings where they are given at all. See Hale v. State; — Md. App. —-, 247 A.2d 409 (Ct. Sp. App. 196́8), where a Maryland court approved as "sound police practice" the reading of warnings from standardized cards. For a list of studies on the effect of Miranda and police compliance, see Medalie, Zeitz \& Alexander, $i d$. at 1349 n.il.

17 Johnson v. Zerbst, 304 U.S. 458, 464 (1938).

18 This approach to "waiver" issues is analytically useful since it avoids some of the confusion that springs from the employment of the term "waiver." A literal emphasis on the notion of "waiver" renders the concept of fifth amendment waiver somewhat paradoxical: Since the privilege against self-incrimination, by its terms, forbids compulsion to speak, a waiver of the privilege literally denotes consent to compulsion; yet "it has never been doubted that the privilege against self-incrimination, like all privileges . . . , is waivable." 8 WIGMORE $\$ 2275$.

19 See, e.g., 384 U.S. at 475.

20 The courts require that the right to counsel at trial be afforded the protection of the court, Von Moltke v: Gillies, 332 U.S. 708 (1948), and that any effective waiver be voluntarily and intelligently exercised. Uveges v. Pennsylvania, 335 U.S. 437 (1948); Bute v. Illinois, 833 U.S. 640 (1948). Failure to request the assistance of counsel at trial does not constitute a waiver under the sixth amendment, Gibbs v. Burke, 337 U.S. 773 (1949), and waiver will not be presumed from a silent record, Garnley v. Cochran, 369 U.S. 506 (1962). See United States v. Glasser, 315 U.S. 60 (1942) (refusal to find a waiver of the right to counsel at trial even though the defendant was himself an attorney). 
dards appear to apply for waiver of the fourth amendment right not to be subjected to an unreasonable search and seizure. ${ }^{21}$

In the proceedings to which the fifth amendment privilege applied prior to Miranda, ${ }^{22}$ the standards for waiver of the privilege often appeared to be less stringent than waiver standards for either fourth or sixth amendment rights. ${ }^{23}$ Miranda guarantees both fifth and sixth amendment rights to an in-custody suspect. Accordingly, the Court's waiver rules reflect the distinction between waiver standards for the fifth amendment privilege and those for the sixth amendment right to counsel, since the absence of counsel at the interrogation markedly raises the standards that must be met. ${ }^{24}$

Prior to Miranda, the privilege could be waived either by contract or other binding pledge before trial or, more commonly, by voluntary

21 A defendant may waive his fourth amendment right at the time the search and seizure is made (by "consent" to a search) or at a later time (by procedural waiver of the opportunity to litigate an asserted denial of the right at a later judicial proceeding, as by failure to assert its deprivation). Where waiver is made by consent to a search, the burden of showing that consent was freely given is on the government. Judd v. United States, 190 F.2d 649 (D.C. Cir. 1951). But many jurisdictions do not require that a specific warning of fourth amendment rights be made. See, e.g., Rosenthall v. Henderson, 389 F.2d 514 (6th Cir. 1968); Gorman v. United States, 380 F.2d 158 (lst Cir. 1967). Contra: United States v. Nikrasch, 367 F.2d 740 (7th Cir. 1966); United States v. Noderacki, 280 F. Supp. 633 (D. Del. 1968); United States v. Blalock, 255 F. Supp. 268 (E.D. Pa. 1966).

22 Before Miranda, the protection of the fifth amendment privilege extended "to all manner of proceedings in which testimony is legally compellable, whether litigious or not and whether ex parte or otherwise. It therefore applies in all kinds of courts (including juvenile courts, when constituted as criminal courts), in all methods of interrogation before a court, in coroner's inquests, in investigations by a grand jury, in investigations by a legislature or a body having legislative functions, and in investigations by administrative officials." 8 WIGMORE $\$ 2266$. See Murphy v. Waterfront Comm'n, 378 U.S. 52, 94 (1964).

23 See generally 8 WIGMORE $\$ \S 2275,2276$, and cases cited therein. A witness who makes a partial admission may not be able to invoke the privilege to avoid answering further questions, even if a reasonable probability of later punishment would flow from answering; see Rogers v. United States, 340 U.S. 367 (1951) (by answering that she had been the treasurer of the Communist Party organization and that she had turned the records over to "someone else," the witness waived the privilege at grand jury proceedings with respect to the identity of the person to whom she had given the books). Waiver of the privilege may also be inferred if the witness takes the stand to testify voluntarily; see Brown v. United States, 356 U.S. 148, 156 (1958) ("Petitioner, as a party to the suit [a denaturalization proceeding], was a voluntary witness. She could not take the stand to testify in her own behalf and also claim the right to be free from cross examination on matters raised by her own testimony on direct examination.")

24 Although a showing of adequate warnings and effective waiver may not be necessary if counsel is present at the interrogation, 384 U.S. at 466 , the Court stressed that a "heavy burden" rests on the government to prove waiver if a statement is taken in the absence of counsel. $I d$. at 475 . While the presence of an attorney may permit continued questioning even after an accused indicates a desire to remain silent, id. at 474 n.44, the individual's right to terminate questioning is absolute in the absence of counsel. Id. at 473-4. 
testimony in court. ${ }^{25}$ Aside from the directive that "an express statement that the individual is willing to make a statement followed closely by a statement could constitute a waiver,"26 there is little specific language in Miranda to explain how law enforcement officials are to ascertain whether an in-custody suspect has knowingly and intelligently waived his rights. ${ }^{27}$ But the Court does set forth a number of instances in which a waiver will not be presumed. ${ }^{28}$

Under the Court's new rules a waiver of the privilege during custodial interrogation differs from a waiver of the privilege in other proceedings in several important aspects. First, the witness or defendant at trial, whether or not represented by counsel, may waive his right to silence without being informed of it, but the interrogation suspect must be told of his rights to silence and to the presence of counsel before he can effect a valid waiver. Second, although the witness or defendant who testifies in other proceedings is often held to have waived his privilege for reasons which have little to do with his subjective intent, ${ }^{29}$ an in-custody waiver of privilege arises only when

25 8 WIGMore $\S 2275$. It should be emphasized that the subject of discussion is waiver of the substantive constitutional privilege itself, as opposed to waiver of the opportunity to litigate an asserted denial of that right at a later judicial proceeding by failure to assert its deprivation. See Commonwealth v. Satchell, 480 Pa. 443, 243 A.2d 381 (1968); Hammonds v. State, 422 P.2d 39 (Alas. 1968).

20384 U.S. at 475.

27 In a significant footnote the Court notes that "the interviewing agent must exercise his judgment in determining whether the individual waives his right to counsel. Because of the constitutional basis of the right, however, the standard for waiver is necessarily high. And, of course, the ultimate responsibility for resolving this constitutional question lies with the courts." Id. at 486 n.55.

- $28 \mathrm{~A}$ waiver is automatically invalid if the required warnings are not given. Failure to request an attorney does not constitute a waiver and "no effective waiver of the right to counsel during interrogation can be recognized unless specifically made" after warnings. Id. at 470. Waiver can never be presumed from a silent record or "simply from the silence of the accused after warnings are given or simply from the fact that a confession was in fact eventually obtained," id. at 475; nor can a waiver be found from the fact that the accused answers some questions or gives some information on his own prior to invoking his right to remain silent when interrogated. Id. at 475-6. The Court declared that "any evidence that the accused was threatened, tricked, or cajoled into a waiver will, of course, show that the defendant did not voluntarily waive his privilege." Id. at 476. Moreover, "lengthy interrogation or incommunicado incarceration" is to be considered "strong evidence" in itself that a subsequent statement was not made pursuant to a valid waiver. Id. If at any time the suspect indicates "in any manner" that he wishes to remain silent or that he wishes to consult with an attorney before speaking to police, there must be no further questioning, even if an earlier waiver was validly obtained. Id. at 473-4. Any statements obtained from an accused in violation of these rules are inadmissible against him in criminal prosecutions; no distinctions are to be made between "confessions" and "admissions" or between inculpatory and exculpatory statements. Id. at 476-7.

29 See Note, Waiver of the Privilege Against Self Incrimination, 14 STaN. L. REv. 811, 813 (1962). 
the interrrogation suspect voluntarily elects to waive his privilege. Third, although the witness or defendant at trial is held to have waived his privilege as to at least some matters by testifying, ${ }^{3.0}$ an in-custody waiver of privilege by a suspect extends only as far as he wishes to extend it. Explicitly barring application of the waiver rule of Rogers v. United States to custodial interrogation, 31 the Court in Miranda introduced the concept of a terminable waiver of rights: under the new rules interrogation must be stopped whenever the suspect so requests, even if it has begun after a valid waiver. ${ }^{32}$ Thus an assertion of the privilege in custodial surroundings operates as a ban against interrogation as well as "an option of refusal."

Many of these differences are explained by the sharp divergence between the policies which underlie the doctrine of waiver of rights during custodial interrogation and those which underlie the doctrine of waiver in other proceedings. In police interrogations there is no danger of injury to adverse parties ${ }^{33}$ by depriving them of the power of cross-examination, nor is there the danger that the fact-finding or truth-finding functions of a judge or jury will be impaired by prejudiced or distorted narratives given under pretense of a claim of the privilege. In custodial interrogations the safeguards against intimidation and trickery afforded by publicity, rules of trial procedure, and the presence of counsel and an impartial judicial officer are lacking. Sacrificing the suspect's interest to that of the state would enable law enforcement officials to circumvent the safeguards of the accusatorial, adversary trial, thus undermining one of the fundamental purposes of the privilege - to redress inequalities in resources between state and accused by requiring the prosecution at crimininal trial to "shoulder the entire load." 34

Where the interrogation suspect has volunteered incriminating facts which render other facts or details innocuous, one traditional justification for the doctrine of waiver by testifying remains applicable. Such "ancillary" facts, it may be argued, should not be protected by the privilege because there is no danger of further incrimination in

\footnotetext{
30 Thẹ rules for detẹminning the sçope of waịyẹr byy a wịtnesș or a defendant at trial are by no means uniform. See 8 WIGMoRE $\& 2276$,

31 384 U.S.: at 469 n.45, For a sțatement of the holding in Rogers, see note 23 supra.

32 Id, ąt $473=4$.

33 There is a danger of injury to other șuspęcts held for the same offențe as the personon interrogated. If the suspect interrogated is guilty but claims the privilege, the other suspects are unable to obtain a speedy release from custody. The Miranda Court, however, did not consider this danger to be șignificant. See id. at 482 ,

34 See id. at $460 ; 8$ WIGMORE § 2251 .
} 
view of the prior disclosure. ${ }^{.8}$ This analysis raises, but does not answer, the question who shall decide what facts are ancillary to the prior disclosure. ${ }^{36}$ If police are viewed as adversaries, and not as impartial fact-finders, then the strength of the policies underlying the privilege may justify the Court's rule allowing only the accused himself to determine the extent of waiver, at least in situations where only the police and the accused are present at interrogation.

\section{The Lower Courts' Appliaation of the Miranda Watyer Rules}

Once it has been determined that adequate Miranda warnings have been administered, courts have examined the particular facts and circumstances of each case to determine whether a suspect has waived his rights to remain silent and to have the assistance of counsel at the interrogation. ${ }^{37}$ The Miranda Court indicated that it sought to avoid case-by-case inquiries into special circumstances, ${ }^{38}$ but the difficult particular-circumstances approach for judicial review of challenged confession cases enjoys continued vitality under the Miranda waiver rules.

A more troublesome development has been the courts' interpretation of the considerable ambiguities in the Miranda waiver rules to achieve standards for waiver which often seem to undercut many of the Supreme Court's goals. The Court made it clear that its requirement of a voluntary, knowing and intelligent waiver imposed a more rigorous standard for admissibility than the "voluntariness" test, ${ }^{39}$ but

35 See Rogers v. United States, 340 U.S. 367, 374-5 (1951); Foster v. People, 18 Mich. 266, 274-5 (1869).

36 Under the standards for waiver by testifying, a major focus of controversy is what facts are, or should be, considered ancillary to an initial, apparently incriminating disclosure. See Note, Waiver of Privilege Against Self-Incrimination, 14 STAN. L. REv. 811 (1962); Boudin, The Constitutional Privilege in Operation, 12 LAw, GuiLD REv. 128 (1952).

37 See, e.g., Narro v. United States, 370 F.2d 329-30 (5th Cir. 1966): "[T] it is clear that the warnings have been given must be considered on their own facts in order to determine the question of waiver. The courts must do this on an ad hac basis, since no per se rule has been adopted dealing with the problem."

38 384 U.S. at 468-9: "Assessments of the knowledge the defendant possessed, based on information as to his age, education, intelligence, or prior contact with authorities, can never be more than speculation; a warning is a clear:cut fact." See $i d . n .38$.

The case-by-case examination of the circumstances of each interrogation and the conduct of each defendant under the traditional "voluntariness" test proved extremely complex and produced extraordinary divisions in the Court on confessions issues. See Ritz, Twenty-fize Years of State Criminal Confessions Cases in the U.S. Supreme Court, 19 WASH. \& LEE L. REV. 35 (1962).

39 "In these cases, we might not find the defendants' statements to have been involuntary in traditional terms.... The fact remains that in none of these cases did the officers under: take to afford appropriate safeguards at the outset of the interrogation to insure that the statements were truly the product of a free chaice." 384 U.S. at 457. 
once the required warnings have been given the emerging lower court standards for waiver of a suspect's Miranda rights often appear to be indistinguishable from the traditional standard for admissibility. Several courts applying the Miranda rules have ignored the question of waiver entirely, in effect finding a waiver from the fact of a voluntary statement after warnings.40

In analyzing the response of the lower courts to the Miranda waiver rules, it is appropriate to examine several recurring factual situations which illuminate particular ambiguities in the Miranda opinion. A rough but useful classification is to group the waiver issues into four categories: the form, content, and timing of a Miranda waiver; police practices affecting the validity of a waiver; multiple interrogation sessions; and the suspect's powers of resistance.

\section{A. The Form, Content, and Timing of a Waiver of Miranda Rights}

The Miranda opinion does not make clear what post-warning actions and words of a suspect are necessary to constitute a valid waiver. Questions such as whether an express, affirmative statement of waiver is required by Miranda, whether the oral waiver of a suspect who refuses to make a written statement of waiver is valid, what form of oral statement is sufficient to establish a suspect's intention to waive his rights, and whether any interrogation may take place before the accused has waived his rights have not yet been resolved satisfactorily by the lower courts.

1. The Necessity for an Express, Affirmative Statement of Waiver. One of the sharpest waiver controversies raised after Miranda focuses on the necessity for an express, affirmative statement of waiver-written or oral-after warnings have been administered. The Miranda opinion is ambiguous on this issue, although the dissenting opinions

40 See, e.g., Embrey v. State, _ Ala. _—, 214 So.2d 567 (1968), where the interrogating officer testified that the accused knew "what he was doing" and "seemed to want to cooperate in trying to get down to the truth." The Alabama Supreme Court, finding that adequate warnings had been administered and that no threats had been employed, stated simply that "[t]here is nothing in this record even remotely tending to show that the defendant expressed a desire to consult with a lawyer before or after the questioning or to have a lawyer present at the questioning." "[W]e are of the opinion that no violation of Miranda is shown." Id. at —, 214 So. $2 d$ at 572. See also State v. Auger, 43 S.W.2d 1 (Mo. 1968), where the Supreme Court of Missouri held admissible statements by a suspect who said that he understood the warnings, but refused to sign a written waiver form, although he stated that "he didn't mind talking about it," after which he proceeded to discuss all the details of the crime freely. Scrupulously avoiding any mention of the "waiver" concept, the Missouri court found that "upon this evidence the admission and statements were not, as a matter of law, involuntary and they were not inadmissible upon that basis." Id. at 6. 
of both Justice Clark and Justice Harlan indicate that an affirmative statement of waiver is now required.41

Two interpretations of particular passages in Miranda have emerged from decisions holding that an express, affirmative waiver is not required. The first is that a "fully effective equivalent" of the warnings and waiver specified by Miranda may be found in the facts and circumstances of the particular case.42 The second is that the Miranda opinion, by specifying that an express statement "could" constitute a waiver, does not rule out other possibilities. ${ }^{43}$

When interrogation is pursued in the absence of counsel, the "fully effective equivalent" interpretation appears to be unsound. The qualification that warnings and waiver are required only in the absence of a "fully effective equivalent" stems from the Miranda Court's desire to stimulate experimentation by the states with alternative systems; ${ }^{44}$ it anticipates the employment of procedural safeguards which will take the place of both warnings and waiver. The Court suggested that provision of station house counsel is one such acceptable alternative.45 Another often-suggested alternative procedure is requiring that an explanation of the nature and significance of the rights to silence and the presence of counsel at interrogation be given by a magistrate, and that waivers be made under judicial supervision. ${ }^{48}$ Where such alternative procedures are not employed, there would appear to be no sound basis

41 "Indeed, even in Escobedo the Court never hinted that an affirmative 'waiver' was a prerequisite to questioning; ...", 384 U.S. at 502 (Clark, J., dissenting). "To forgo these rights, some affirmative statement of rejection is seemingly required, . . ., id. at 504 (Harlan, J., dissenting); and at 516, "To require also an express waiver by the suspect and an end to questioning whenever he demurs must heavily handicap questioning." Several commentators have so interpreted Miranda. See N. SOBEL, THE NEW Confession Standards -Miranda v. Arizona 75 (1966); B.J. George, JR., Constitutional Limitations on Evidence in Criminal Cases 119, 120 (1966); A New Look at Confessions: Escobedo-The Second Round 76 (B.J. George, Jr. ed. 1967).

42 See United States v. Hayes, 385 F.2d 375 (4th Cir. 1967), cert. denied, 390 U.S. 1006 (1968); Mullaney v. State, — Md. App. — 246 A.2d 291 (Ct. Sp. App. 1968); Brown v. State, 3 Md. App. 313, 239 A.2d 761 (Ct. Sp. App. 1967).

43 See Sullins v. United States, 389 F.2d 985, 989 (10th Cir. 1968) (Lewis, J., dissenting):

I do not agree, as I read the main opinion to hold, that an express declination of the right to counsel is an absolute from which, and only from which, a valid waiver can flow. Miranda states that such a declination followed closely by a statement

"could" constitute a waiver. It does not negate other possibilities.

The dissenting view in Sullins was adopted in dictum by the 10th Circuit in Bond v. United States, 397 F.2d 162 (10th Cir. 1968), where the defendant signed a formal written waiver of rights prior to any questioning.

44384 U.S. at 467.

$45 \mathrm{Id}$. at 466 . "The presence of counsel, in all the cases before us today, would be the adequate protective device necessary to make the process of police interrogation conform to the dictates of the privilege."

46 See Developments, 79 HARv. L. REv. at 1007. 


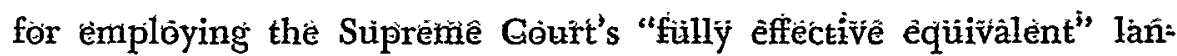
guage to hold that an express statemenente of wâiver is noot required.

The "other possibilities" intërpretétion is mòoré pläưsiblê. This interpretation seems sometwhàt inceonsistent with the Gourt's àminbiguiouis directive that àny waiver of the right to cóunsèl must be "specifieally made," but "spëcifically made" may ơ mây not meân àn express stätement ${ }^{47}$ and the context of the "specifically made" passage makes it at least questionable that this passage was intended to be a decisive pronouncement of the Court's standards for waiver. ${ }^{48}$ If this añalyšis is sound, the Miranda opinion does not require an express waiver in all cases.

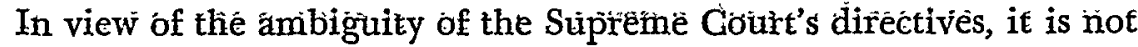
surprising that the lower courts have divided on whether an affirmative statemenent of waiver is an âbsolutue prérequisite to admissibility under Miranda.49 The prineipal casè hölding thá àn expiresš statemènt of waivef is nôt reequired is United Stâtês $v$ : Hayes. ${ }^{50}$ The unusual facts

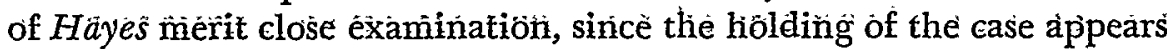
to hàve beenen èxtended imprudeñtlỳ by othér courts. Hayyès was arrésted

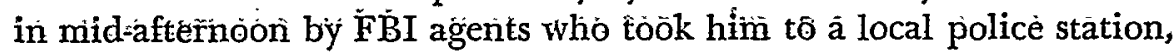

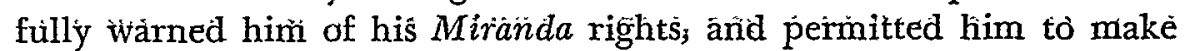
ä phone call. The agents did not ask Hayes if he understoood the Mirañda $a$ warninings ôr desired counsèl, and he did not voolunteer any such information. After approximately thirty minutes of questioning,

47 See Sullins v. Únited States, 389 F.2d 985 (10th Cir. 1968), where the court split on this question.

48 "An individual need not make a pre-interrögation réquest for à lawyer. Whîile such request affirmatively secures his right to have one, his failure to ask for a lawyer does nòt constitute a waiver. No effective waiver of the right to counsel during interrogation can be recognized unless specifically made after the warnings we here delineate have been given. The accused who does not know his rights and therefore does not make a request may be the person who most needs counsel." 384 U.S. at 470-1. The Court's emiphasis seems tó be that a valid waiver, however it is made, can only be effected after warnings have been administered.

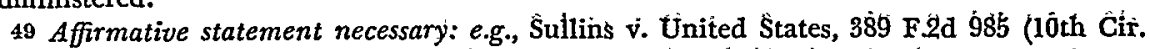
$196 \hat{8})$; Ṕpople v. Anónymous, —- Misc. 2d —-, 294 N.Y.S.2d 248 (Nassau County Ct. 1968); People v. Jacobson, — Misc. 2d —, 294 N.Ỳ.S.2d 46 (Nassáu Cóunty Cit. 1968); People v. Kessler 33 Misc. 2d 26ं8; 278 N.Y.S.2d 423 (Allegany County Gt. 1967). Affirmative statement not necessầry: è.g., United Stătès v. Haỳes 3835 F.2́d 375 (4th Gir. 1967), cert.

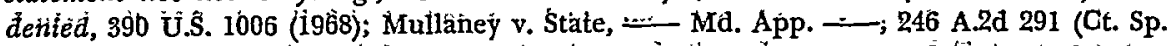
Ap̀p. 1968); Bł́wn v. State, 3 Ma. App. 313, 239 A.2̀ 761 (C̈t: Sp: Aṕp. 1967). Sevèral courts have, without discussing the point, in effect fouñd a valid wäivè in the àbsénce óf an affirmative oral or written statement of waiver. See, e.g., Alexander v. United śtátés, 380 F.2d 33 (8̂th Cir. 196́7); People v. LaVergnè, 64 Cal. 2d 265, 411 P.2a 309, 49 Gal. Rptr. 557 (1967); Peóplé v. Hill, 39 Ill: 2d 125, 233 N.E.2d $36 f$ (1968); Stăte v̀. Fostèr; 二 Kan. $-4,447$ P.2d 405 (1968); Charles v. State of Texas, 424 S.W.2d 909, (Tex. Crim. Ċt. Ap̈p. 19.67).

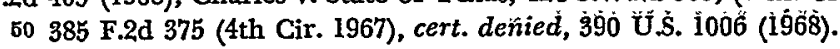


which elicited incriminating statements later used at his trial, he suddenly terminated the interrogation by declaring that he would not answer further questions and demanded that he be allowed to see a lawyer. Hayes never confessed. The Fourth Circuit, affirming his conviction for transporting counterfeit checks in interstate commerce, expressly rejected Hayes' contention that a waiver of rights could not be found in the absence of an express post-warning statement of waiver. ${ }^{.1}$ The caurt stated that an affirmative statement is "not an essential link in the chain of proof" of waiver and the "mere absence of such a statement will not preclude as a matter of law the possibility of an effective waiver." 52

Finding a waiver of Miranda rights in the absence of an express statement of waiver seems appropriate only in an extremely narrow range of situations. In Hayes the suspect's later assertion of his rights made it clear, despite his silence after warnings, that he had understood the warnings, that he was aware of his rights and knew how to exercise them, and that he consented at first to be questioned. Where a suspect's silence in response to warnings is followed only by a statement or by answers to questions, these inferences will seldom stand out as clearly. The holding of some courts that an affirmative statement of waiver is not required in such cases $^{53}$ seems unwarranted. This approach, which in effect finds a waiver from the fact that a suspect has been warned and has subsequently made a voluntary statement, closely resembles the standard, explicitly rejected in Miranda, which presumes a waiver from the fact that an accused eventually confesses after police warnings are administered. If the Court's new waiver rules were intended to impose a stricter standard for ad-

\footnotetext{
51 Id. at 378:

Miranda admonishes: "The warnings required and the waiver necessary in accordance with our opinion today are, in the absence of a fully effective equivalent, prerequisites to the admissibility of any statement made by a defendant." (Emphasis supplied). . . . We simply decide today that strong and unmistakable circumstances, upon occasion, may satisfactorily establish such an equivalent.

52 Id. at $377-8$.

63 See Mullaney v. State, — Md. App. — 246 A.2d 291 (Ct. Sp. App. 1968), where a Maryland court found that a voluntary and intelligent waiver was established by the testimony of police that the suspect "shook his head like he understood" and "just nodded his head in a yes position" in response to a post-warning inquiry whether, "having these rights in mind," he wanted to talk to the police. Officers at the site of the arrest proceeded to question the accused, although he appeared "sullen and angry" and did not respond at all to police questions until some time later, while he was being taken to the police station. Cf. United States v. Hayes, supra note 50, at 378 , where the Hayes court noted that "mere silence of the accused followed by grudging responses to leading questions will be entitled to very little probative value in light of the inherently coercive atmosphere of in-custody interrogation."
} 
missibility than the earlier "voluntariness" test, more than a showing of warnings followed by a suspect's apparent willingness to answer questions should be required to establish a valid waiver. ${ }^{54}$

Two major policies would be served by requiring an express, affirmative statement of waiver in all cases as an absolute prerequisite to admissibility. First, since police interrogators would be required to ask for a statement of waiver if the suspect did not volunteer one, such a requirement would advance the goal of assuring that the suspect is made aware of "his interrogators' willingness to recognize his rights should he choose to exercise them." Second, although a "boilerplate statement" of waiver may not be sufficient in itself to establish the validity of a waiver, since such a statement could always be the result of coercion, ignorance, or diminished intelligence, ${ }^{55}$ the presence of an affirmative statement would be a readily ascertainable fact, which would substantially lessen the burden of the reviewing court, particularly in cases where the suspect exhibits inconsistent or vacillating intentions at the interrogation.

These considerations apply with equal force to the holding of some courts that a valid waiver is established by a post-warning statement that the suspect understands (as opposed to waives) his rights. ${ }^{56}$ Glearly an individual may understand his rights without wishing to waive them. ${ }^{57}$ Since it is unlikely that a suspect would manifest his decision to cooperate with the police by refusing to give an express waiver or by giving an ambiguous statement of waiver, law enforcement officials should experience no difficulty in obtaining an express waiver from those suspects who are in fact willing to waive their rights.

2. The Sufficiency of Oral and Written Statements of Waiver. Like

54 Thus, in Proctor v. United States, 404 F.2d 819 (D.C. Cir. 1968) (Wright, J.), the court emphasized that Miranda requires that " [ $t]$ ] be an allegation and evidence which show, that an accused was offered counsel but intelligently and understandingly rejected the offer. Anything else is not waiver.'" Id. at 821 (quoting 384 U.S. at 475 , emphasis by the court). The court went on to say: "The immediate availability of offered counsel at the place of interrogation is, of course, a primary consideration in determining the bona fides of the offer and the validity of the waiver." Id. at 822.

55 See 384 U.S. at 492, where the Court said of Miranda's signed confession "[t]he mere fact that he signed a statement which contained a typed-in clause stating that he had 'full knowledge' of his 'legal rights' does not approach the knowing and intelligent waiver required to relinquish constitutional rights."

56 See People v. Stewart, 264 Cal. App. 2d 944, 70 Cal. Rptr. 873 (Ct. App. 1968); People v. Midkoff, 262 Cal. App. 2d 804, 68 Cal. Rptr. 866 (Ct. App. 1968); People v. Carter, 258 Cal. App. $2 d$ 727, 65 Cal. Rptr. 845 (Ct. App. 1968); People v. Fuller, - Cal. App. 2d — 74 Cal. Rptr. 488 (Ct. App. 1969). Contra, People v. Anonymous, - Misc. 2d -, 294 N.Y.S.2d 248 (Nassau County Ct. 1968).

57 See People v. Anonymous, — Misc. 2d —, 294 N.Y.S.2d 248 (Nassau County Ct. 1968). 
the requirement of an express, affirmative statement of waiver, a categorical requirement of a written waiver of Miranda rights would avoid some "swearing contests" at trial between police interrogators and the suspect and would help to impress a suspect with an appreciation that his statements can be used in evidence against him. Nevertheless, the Supreme Court's new waiver rules do not demand that waivers be made in writing, and the lower courts have held that a waiver of Miranda rights may be written ${ }^{58}$ or oral, ${ }^{59}$ and may be made spontaneously by the suspect as a reaction to the Miranda warnings or elicited by inquiries from interrogators after warnings have been given..$^{60}$

A noteworthy complication arises when a suspect willingly talks to police interrogators but refuses to execute a waiver in writing. ${ }^{.1}$ In cases where other indications of the suspect's intentions to waive are ambiguous, some courts have considered such a refusal as a circumstance indicating that a purported oral waiver was not validly obtained, ${ }^{62}$ but many lower courts have upheld the validity of an oral waiver despite an express refusal to make a waiver in writing. ${ }^{63}$ The Attorney General of California noted recently that if signed waivers became the general rule, undue significance could attach to a suspect's

58 See, e.g., Lopez v. United States, 399 F.2d 865 (9th Cir. 1968); West v. United States, 399 F.2d 467 (5th Cir. 1968); United States v. Hall, 396 F.2d 84I (4th Cir. 1968).

59 See, e.g., United States v. Boykin, 398 F.2d 483 (3d Cir. 1968); United States v. Corbbins, 397 F.2d 790 (7th Cir. 1968); Miller v. United States, 396 F.2d 492 (8th Cir. 1968); Solino v. United States, 387 F.2d 354 (5th Cir. 1968); Keegan v. United States, 385 F.2d 260 (9th Cir. 1967).

co See, e.g., United States v. Hall, 396 F.2d 841 (4th Cir. 1968) (written); Miller v. United States, 396 F.2d 492 (8th Cir. 1968) (oral).

61 See, e.g., Hodge v. United States, 392 F.2d 552 (5th Cir. 1968).

62 In People v. Thiel, 26 App. Div. 2d 897, 274 N.Y.S.2d 417 (1966) the defendant, during interrogation, stated only that he would talk to a trooper and would not sign a statement. The New York court held that the defendant's response, when considered in light of his tenth grade education and lack of previous experience with the police, fell considerably short of indicating that "he understood the full import of the officer's statement and that he knowingly waived his right to counsel," $i d$. at 897,274 N.Y.S.2d at 418 , and indicated instead that he was not willing to give a statement in a form which could be used in evidence against him. In United States v. Nielsen, 392 F.2d 849 (7th Cir. 1968), the defen. dant told interrogators that he had retained counsel and would not sign a waiver of rights form or "anything" until he had spoken to his attorney. However, he declined to call his attorney, saying that he would call later in the morning, and he said that questioning could continue. The Seventh Circuit held that the defendant's responses indicated that he desired to remain "silent," and that the inconsistency of the defendant's refusal to sign the waiver form, followed by an apparent willingness to allow further questioning, should have alerted the agents to inquire further to ascertain whether "his apparent change of position was the product of intelligence and understanding or of ignorance and confusion." Id. at 853.

63 See, e.g., Hodge v. United States, 392 F.2d 552 (5th Cir. 1968); Keegan v. United States, 
refusal to sign a written waiver form, since " $[\mathrm{m}]$ any experienced defendants are willing to talk but absolutely refuse to sign anything." $" 4$ Yet a suspect's refusal to execute a written waiver seems to reflect some hesitancy to abandon his Miranda rights. Where the suspect has had little or no previous exposure to police interrogation and subsequent criminal prosecution, it may even be doubtful that the suspect is in fact aware that he is relinquishing his legal rights by making an oral statement of waiver. If written waivers are not required, it should be incumbent upon police interrogators to make it clear to the suspect that an oral waiver is just as binding as a written waiver and may be of equally decisive legal effect.

The form of an oral waiver sufficient to establish a suspect's intention to waive is apparently quite flexible. The courts have generally rejected the argument that a formal recitation of waiver- "I have no desire to remain silent and I do not want an attorney" - is necessary, ${ }^{65}$ and a wide range of oral expressions have been held sufficient to effect a valid waiver ${ }^{66}$ unless the statement is ambiguous ${ }^{67}$ or there is evidence of police coercion. ${ }^{68}$

Even in the absence of ambiguity or evidence of coercion, however,

358 F.2d 260 (9th Cir. 1967), cert. denied, 391 U.S. 967 (1968); Tucker v. United States, 375 F.2d 363 (8th Cir.), cert. denied, 389 U.S. 888 (1967); United States v. Jackson, 287 F. Supp. 80 (D. Conn. 1968); United States v. Burley, 280 F. Supp. 672 (D. Del. 1968); State v. Magee, 52 N.J. 352, 245 A.2d 339 (1968); State v. McKnight, 52 N.J. 35, 243 A.2d 240 (1968).

64 B.J. George, JR., A New LoOK at Confessions: Escobedo-The Second Round 76 (1967).

65 State v. Kremens, 52 N.J. 303, 245 A.2d 313 (1968); Brisbon v. State, 201 So. 2 d 832 (Fla. Dist. Ct. App. 1967).

66 See, e.g., United States v. Boykin, 398 F.2d 483 (3d Cir. 1968) ("I might as well tell you about it."); Keegan v. United States, 385 F.2d 260 (9th Cir. 1967) ("I don't have nothing to hide. I will answer anything within reason."); Soolook v. State, 447 P.2d 55 (Alas. 1968) ("Oh well, I might as well tell you about it now."); Commonwealth v. Fisher, — Mass. —_, 238 N.E.2d 525 (1968) (“I will."); State v. Ransom, 182 Neb. 243, 153 N.W.2d 916 (1967) ("Yes."); State v. Graves, — S.D. - 163 N.W.2d 542 (1968) ("I will answer what I can.")

67 See United States v. Nielsen, 392 F.2d 849 (7th Cir. 1968) (statement that interrogators "could proceed with the questioning" insufficient where defendant had earlier refused to sign a waiver form until he had spoken with his attorney but had declined to call his attorney, saying "it could wait until later."); Craig v. State, 216 So. 2d 19 (Dist. Ct. App. Fla. 1968) (alternate holding) (defendant's statement that "in a way" he would like to have an attorney, but that he did not "see how it can help me" held inadequate to constitute a clear and unequivocal waiver); People v. Thiel, 26 App. Div. 2d 897, 274 N.Y.S.2d 417 (1966) (defendant's statement that he would talk to a trooper but would not sign a statement, when considered in light of his educational background and lack of previous experience with the law, insufficient to waive counsel). See also Brown v. Heyd, 277 F. Supp. 899 (E.D. La. 1967) ("I know all of that" insufficient to waive the accused's right to Miranda warnings).

68 See United States v. Low, 257 F. Supp. 606 (W.D. Pa. 1966) ("All right" held insuffcient to effect waiver where the suspect was interrogated between 1:00 and 2:00 AM and was told by police that it would be easier on him if he cooperated). 
closer judicial scrutiny should be given to the form of police questions which elicit a suspect's oral statement of waiver. The finding of one recent study ${ }^{69}$ that a significant number of suspects fail to understand the Miranda warnings suggests that to ensure an informed choice by the suspect to speak or to remain silent, interrogating officers should be required to explain both the Miranda warnings and the nature and meaning of a "waiver" of constitutional rights. A formal reading of warnings followed by a request for a "waiver" may be less meaningful to a suspect than the questions: Do you understand that you don't have to answer any questions, that you can have a lawyer here with you before we ask you any questions, and that if you want an attorney we will get one for you now, without charge? Do you understand that anything you say can be used in evidence against you at a later trial? Knowing this, do you still want to answer our questions now without a lawyer? Unless police interrogators take pains to insure that a suspect does in fact understand both his legal rights and the significance of waiving these rights, the procedure of warnings and waiver may be only an ineffective preliminary ritual to interrogation.

3. The Need for a Waiver Prior to Any Interrogation. The Court explicitly stated that four-fold warnings of legal rights must precede all interrogation of an in-custody accused. ${ }^{70}$ Whether a waiver of rights must also precede custodial interrogation is unclear from the Miranda opinion. ${ }^{71}$ The majority opinion comes close to saying that there can be no interrogation of an in-custody accused before a waiver, ${ }^{72}$ but the Court does not expressly and unequivocably forbid custodial interrogation after warnings have been given and before a waiver is obtained, as long as the prosecution introduces into evidence only those statements which were made after a waiver.

\footnotetext{
69 See Medalie, Zeitz \& Alexander, Custodial Police Interrogation in Our Nation's Capital: The Attempt to Implement Miranda, 66 MicH. L. REv. 1347, 1875-6 (1968).

70384 U.S. at $444,467-8,479$.

71 It may be permissible for police to ask some questions before obtaining a waiver, so long as they do not interrogate the suspect. "Surely, the suspect can be asked what he wants for lunch without securing a waiver of rights, even though one can conjure up cases in which the answer would turn out to be incriminating." Graham, What is "Custodial Interrogation?": California's Anticipatory Application of Miranda v. Arizona, 14 U.C.L.A.L. REv. 59, 96 (1966). But see Proctor v. United States, 404 F.2d 819 (D.C. Cir. 1968) (Wright, J.).

72 For example, the Court states that "Opportunity to exercise these rights must be afforded to him throughout the interrogation. After such warnings have been given, and such opportunity afforded him, the individual may knowingly and intelligently waive these rights and agree to answer questions or make a statement." 384 U.S. at 479. "The fundamental import of the privilege while an individual is in custody is not whether he is allowed to talk to the police without the benefit of warnings and counsel, but whether he can be interrogated." Id. at 478. The dissenting opinions of Justices Clark and White interpret the majority opinion as holding that a waiver of rights must precede interrogation. See $i d$. at $502,537-8$.
} 
This issue has rarely been litigated; one court, however, has held that an express waiver must precede all custodial interrogation. ${ }^{73}$ Even commentators expressing their hostility to the Supreme Court's limitations on police interrogations have assumed that under the new rules interrogation cannot begin until after a valid waiver. ${ }^{74}$ A "waiver" which results only after some interrogation by police may well be the product of the interrogation rather than of the suspect's "free and informed" choice. Requiring an express waiver before any interrogation would guard against this danger and would provide a major bulwark for preventing the interrogation of a suspect against his will, a concern implicit in Miranda's holding that interrogation must be stopped whenever the suspect so requests, even if it has begun after a valid waiver. ${ }^{75}$

\section{B. Police Practices Affecting the Validity of a Waiver}

The Miranda waiver rules enable the courts to exercise some supervision over the post-warning practices of police interrogators, since the validity of a waiver is affected by the conduct of police after warnings have been given. ${ }^{76}$ The general requirement that a waiver be made "voluntarily," and the Court's explicit prohibitions against lengthy interrogation, incommunicado detention, and obtaining a waiver by threats, trickery, or cajolery seem to strike directly at police abuses and suggest that a "police practices" analysis of the type utilized by the courts under the "totality of circumstances" test" is appropriate under the Supreme Court's new waiver rules.

1. Interrogation Tactics. To what extent the Court's waiver rules inhibit police conduct is uncertain. For instance, the Court stated that "Iengthy interrogation" is to be considered as "strong evidence" of an invalid waiver, ${ }^{78}$ but a different result may be reached in a particular case depending upon whether the number of questions, the number of minutes it takes police to ask them, or the total time the suspect is in custody is taken as the appropriate measure of the "length" of questioning. ${ }^{79}$ Even greater difficulties attach to the Court's proscrip-

73 People v. Keesler, 53 Misc. 2d 268, 278 N.Y.S.2d 423 (Allegany County Ct. 1967). 74 See F. Inbau \& J. Reid, Criminal INterrogation and Confessions 4-5 (2d ed. 1967). 75384 U.S. at $473-4,475-6$.

70 See 384 U.S. at $475-7$.

77 See Developments, 79 Harv. L. REv. 935, 969 (1966). Under the "totality" view the Supreme Court has considered such police tactics as physical abuse, threats, extensive questioning, and incommunicado detention. See note 2 supra.

78384 U.S. at 476.

79 Graham, What is "Custodial Interrogation?": California's Anticipatory Application of Miranda v. Arizona, 14 U.C.L.A.L. REv. 59, 98 (1966). 
tion against obtaining a waiver by threats, trickery, or cajolery. ${ }^{80}$ In particular cases it may be difficult to determine whether the actions of police interrogators fall within these categories. ${ }^{81}$ Where the challenged police behavior consists of spoken words, judicial supervision may be particularly difficult. The tone of a detective's voice and the context in which the words are spoken are factors difficult to review, but each may profoundly affect the suspect's decision to waive his rights or answer questions.

The express prohibition in the Miranda opinion of threats, trickery, and cajolery is confined to their use in obtaining a waiver. Although the Court criticized the deceptive strategems advocated by police interrogation manuals, ${ }^{82}$ it did not expressly proscribe such techniques once the required warnings have been given and a waiver has been obtained. Inbau and Reid, writing post-Miranda, maintain that "all but a very few of the interrogation tactics and techniques presented in our earlier publication are still valid if used after the recently prescribed warnings have been given to the suspect under interrogation, and after he has waived his self-incrimination privilege and his right to counsel." 83 They continue to advocate many of the tactics expressly criticized by the Supreme Court, such as minimizing the moral significance of the offense ${ }^{84}$ and casting blame on the victim or on society. ${ }^{85}$ Moreover, so long as it is not "of such a nature as to induce a false confession," Inbau and Reid recommend the continued employment of police trickery and deceit to elicit a confession. ${ }^{86}$ A recent study indicates that police interrogators still utilize coercive tactics such as "Mutt and Jeff" routines, outright trickery, relay questioning, and

80384 U.S. at 476.

81 Compare, e.g., People v. Russell, 259 Cal. App. 2d 637, 66 Cal. Rptr. 594 (Ct. App. 1968) (officer's statement that it might be better for the defendant if he talked held a threat which nullified a prior Miranda warning and invalidated a subsequent waiver) with People v. McGuire, 39 Ill. 2d 244, 234 N.E.2d 772 (1968) (officer's statement that it would be better for the defendant if he talked held not to be a threat or inducement).

82384 U.S. at 448-55. The Court was particularly critical of F. INBAU \& J. REID, GriminaL INTERROGATION AND CONFESSIONS (1962).

83 F. INbau \& J. Reid, CRIMINal Interrogation ANd Confessions 1 (2d ed. 1967).

84 Id. at 40-2. Compare 384 U.S. at 450.

85 F. INBaU \& J. Reid, Criminal INTERrogation and Confessions 47-59 (2d ed. 1967). Compare 384 U.S. at 450 .

86 According to Inbau and Reid, leading the suspect to believe that there is more proof of his guilt than actually exists, deceiving the suspect into believing that an accomplice has confesscd and implicated both himself and the suspect, staging mock "identifications" of the suspect by police officers posing as witnesses, and eliciting a handwritten statement of guilt from the suspect by the use of fake notes purporting to come from another prisoner are all tactics recommended "until such time as they may be specifically prohibited." F. INBAU \& J. REID, supra note 85, at 195-7. 
playing off co-suspects. ${ }^{87}$ Many of these tactics would seem vulnerable to constitutional attack, even under the less rigorous standards of due process, but apparently no lower court has held that the utilization of such techniques after both warnings and waiver, of itself, invalidates a waiver. ${ }^{88}$

Deceptive police strategems, however, are clearly inimical to the constitutional foundation underlying the privilege-c"the respect a government ... must accord to the dignity and integrity of its citizens." 89 If the required warnings were designed to protect the privilege of silence by assuring the suspect that he need not speak at all, it seems inconsistent to permit the employment of tactics intended to create in the suspect the impression that he must talk. Such practices appear to be fundamentally at odds with the Court's aim of assuring "that the individual's right to choose between silence and speech remains unfettered throughout the interrogation process." ficult to define standards for proper police interrogation, ${ }^{91}$ but if Miranda's goal of a "free and informed" choice to speak or remain silent is to be taken seriously, it would appear that the utilization of such tactics after both warnings and waiver should materially increase the government's burden to show that the accused made a valid, continuing waiver. It seems paradoxical to treat misleading police conduct unfavorably under the voluntary-confessions doctrine, ${ }^{92}$ while permitting deceptive police practices under the stricter fifth amendment standard.

2. The Necessity for Police Admonitions Beyond the Required Warnings. There are situations in which the standard of a "knowing" waiver may require police interrogators to provide a suspect with more

87 See Project, Interrogations in New Haven: The Impact of Miranda, 76 YALE L.J. 1519, $1542-9$ (1967).

88 This result does not seem to be attributable solely to the difficult problems of proof which must be overcome to establish the historical facts of secret interrogations, even though the lack of a record of an interrogation still appears to be the rule. Before Miranda the California courts apparently held that the employment of such tactics signaled the onset of the "accusatory stage" of criminal investigation, and that such tactics could not, therefore, be utilized unless preceded by the warnings of rights required under the broad California interpretation of Escobedo. See Graham, "What is Custodial Interrogation?": California's Anticipatory Application of Miranda v. Arizona, 14 U.C.L.A.L. REv. at 59.

89384 U.S. at 460.

$00 \mathrm{Id}$. at 469 .

91 See Ali Model Code of Prearraignment Procedure § 5.04, Commentary at 178-9: One of the most difficult questions in connection with the Code is determining what should be provided with respect to the use of deception in seeking information from suspects. The propriety of techniques such as those catalogued in detail in Inbau and Reid, Criminal Interrogation and Confessions (1962), has been the subject of sharply conflicting views.

92 See Spano v. New York, 360 U.S. 315 (1959). 
information than the four-fold Miranda warnings. In a pre-Miranda case, People v. Lacy, ${ }^{33}$ the New York Appellate Division held that a waiver of counsel during interrogation was precluded by the failure to inform an 18 year-old in-custody suspect that an attorney had inquired about him at the place where suspects were normally held after arrest. ${ }^{94}$ The Appellate Division noted that "had the [suspect] been advised that an attorney had appeared to represent him, pursuant to his request at the time of arrest, he may well have chosen to remain silent until counsel had an opportunity to advise him." York court's analysis, the result would now seem to be compelled by Miranda's requirement of a "knowing" waiver. ${ }^{98}$

The Lacy rationale applies only to a limited range of situations. A broader issue is whether police interrogators must inform a suspect of the nature and seriousness of the charges against him. The few decisions which have confronted this question are in conflict.

The Fourth Gircuit recently followed the pre-Miranda rule97 and

9326 App. Div. 2d 982, 274 N.Y.S.2d 944 (1966).

94 Id. at 983, 274 N.Y.S.2d at 947. The Lacy decision rested on exclusionary principles developed from New York's constitutional and statutory provisions pertaining to due process, the privilege against self-incrimination, and the right to counsel. See also People v. Ressler, 17 N.Y.2d 174, 269 N.Y.S.2d 414, 216 N.E.2d 582 (1966); People v. Sanchez, 15 N.Y.2d 387, 259 N.Y.S.2d 409, 207 N.E.2d 356 (1965); People v. Gunner, 15 N.Y.2d 226, 257 N.Y.S.2d 924, 205 N.E.2d 852 (1965); Pcople v. Failla, 14 N.Y.2d 178, 250 N.Y.S.2d 267, 199 N.E.2d 366 (1964); People v. Donovan, 13 N.Y.2d 148, 243 N.Y.S.2d 841, 193 N.E.2d 628 (1963).

9526 App. Div. at 983, 274 N.Y.S.2d at 947.

98 The Court in Miranda deemphasized the sixth amendment rationale of Escobedo and appeared to require counsel only as a device for protecting the fifth amendment privilege. Nevertheless, the Court's apparent concern to encourage the presence of counsel at interrogation has prompted some courts to speculate in dictum that higher standards for waiver should apply to suspects who are known to be represented by retained or appointed counsel. See United States v. Smith, 379 F.2d 928 (7th Cir. 1968); Mathies v. United States, 374 F.2d 812, 316 n.3 (D.C. Cir. 1967).

The New York Court of Appeals (subsequent to the Lacy decision discussed in the text) has promulgated the broad rule that once police become aware that an attorney has entered the proceedings, they may not question the suspect or elicit a waiver from him. See People v. Vella, 21 N.Y.2d 249, 234 N.E.2d 422, 287 N.Y.S.2d 869 (1967). See also People v. Arthur, 22 N.Y.2d 325, 239 N.E.2d 537, 292 N.Y.S.2d 663 (1968). The New York position has not been followed in other jurisdictions. See, e.g., State v. Whitewater, — Ore. 445 P.2d 594 (1968). Several courts have held that an accused may waive his Miranda rights in the absence of and without notice to previously retained or appointed counsel. See Wilson v. United States, 398 F.2d 331 (5th Cir. 1968); Coughlan v. United States, 391 F.2d 371 (9th Cir. 1968); Gunter v. State, 421 S.W.2d 657. (Tex. Ct. Crim. App. 1967). But see dissenting opinion in Coughlan v. United States, 391 F.2d at 374.

97 Pre-Miranda cases did not require police to inform an accused of the precise charges against him or of the range of possible punishments which might ensue from his conviction, even in the dramatic case where, unknown to the accused, his victim had died and possible murder charges were pending against him. See United States ex rel. Kern v. Maroney, 275 F. Supp. 435 (withholding information that victim of robbery had died of stroke); People v. Allen, 8 Mich. App. 408, 154 N.W.2d 570 (1967) (withholding until after incriminating 
rejected the argument that a robbery suspect could not "knowingly" waive his rights unless interrogating officers informed him of the punishment he might receive if convicted.98 Similarly, in State $v$. Lucero,99 the Montana Supreme Court affirmed a murder conviction, finding a waiver because the suspect's exculpatory statements ${ }^{100}$ established that she knew that she was a murder suspect and because she was "adequately advised as to why she was being held, why she was being questioned, and was aware of these matters including the gravity thereof."101 The suspect in Lucero was advised prior to interrogation that she was arrested for "an assault on her husband." The police informed her that her husband was dead and that she was being questioned "concerning her husband," but avoided the word "murder" and did not advise the suspect of the statutory punishment for murder.

In Schenk v. Ellsworth, ${ }^{102}$ the United States District Court for the District of Montana differed with the Lucero result, holding that the requirement of a "voluntary, knowing and intelligent" waiver requires interrogating officers to inform an in-custody suspect of the crime he is suspected of having committed before a statement can be taken. The court emphasized that it was "not establishing a requirement that a suspect be advised with technical precision what formal charge or charges are contemplated,"103 but it found that a statement that police wanted to talk to the defendant "in connection with the shooting incident of his wife" was inadequate to support the defendant's purported waiver of rights since he was not advised that he was suspected of having murdered his wife. ${ }^{104}$ "Certainly it stands to reason that a

statements were obtained, information that man had died in fire set by defendant and that murder charges were pending); People v. Roman, 256 Cal. App. 2d 735, 64 Cal. Rptr. 268 (Dist. Ct. App. 1967) (withholding information of victim's death).

98 United States v. Hall, 396 F.2d 841 (4th Cir.), cert. denied, 393 U.S. 918 (1968). "We do not find in that decision [Miranda] any intimation that knowledge of the punishment for the crime with which he was charged is a prerequisite to a valid waiver of constitutional rights. ..." Id. at 845 .

99 - Mont. —, 445 P.2d 731 (1968).

100 "I didn't cut or kill my husband. I swear I didn't." Id. at —, 445 P.2d at 736.

$101 \mathrm{Id}$. at $\longrightarrow, 445 \mathrm{P} .2 \mathrm{~d}$ at 736. "We are not aware of any requirement that an in-custody suspect, prior to interrogation by law enforcement officers, must be advised with technical precision of a charge not then filed and the penalty upon conviction." $I d$.

102293 F. Supp. 26 (D. Mont. 1968).

103 Id. at 29.

104 "Since Schenk was not advised as to the reason for his detention and questioning, we hold that his waiver was not made knowingly and intelligently." Id. The Schenk court could have found that the defendant did in fact know without an admonition that he was being questioned for the murder of his wife since she died in the defendant's home before police arrived "as a result of a gunshot wound in the neck inflicted at point blank range." Id. at 27. The court noted, however, that the defendant's later query of an interrogating county attorney whether he thought he needed an attorney cast "extreme 
suspect cannot intelligently make the decision as to whether he wants counsel if knowledge of the crime suspected is withheld from him. This knowledge is a necessity for the free exercise of the right to counsel." 105

Since Miranda specifically requires only four warnings, it could be argued that the Court contemplated that no further warnings were necessary to protect the privilege of silence during custodial interrogation. Nevertheless, the Schenk decision is in accord with the Supreme Court's rationale for warning a suspect that his statements may be used in evidence against him. ${ }^{106}$ In Johnson v. New Jersey ${ }^{107}$ the court explained that Miranda was "designed in part to assure that the person who responds to interrogation while in custody does so with intelligent understanding of his right to remain silent and of the consequences which may flow from relinquishing it." 108 Unless a suspect is aware of the nature and seriousness of the crime for which he is interrogated, he cannot understand intelligently the consequences which may flow from relinquishing his Miranda rights. The defendant at trial must be informed of the charges against him and the possible range of punishments before he can waive his right to counsel. ${ }^{109}$ The Court's repeated reference to the functional equivalence of trial and pre-trial questioning ${ }^{110}$ suggests that police must provide an in-custody suspect with similar information prior to interrogation.

It may not be possible in all cases for interrogators to give notice of the technical charge which will be filed against a suspect. ${ }^{111}$ When such information is not known, the police should at least inform the suspect of the nature and seriousness of the crime they are investigating. Requiring interrogators to give this warning would prevent police misrepresentation of the gravity of the charge and would simplify the reviewing court's difficult inquiry to determine if the suspect has "knowingly" waived his right to remain silent.

doubt as to Schenk's understanding of the circumstances of his detention and interrogation." Id. at 28. "As matters stood, Schenk was very likely misled, wittingly or unwittingly, by the county attorney in regard to why he was being detained and questioned." Id. (emphasis added).

$105 I d$. at 29.

106 "This warning is needed in order to make him aware not only of the privilege, but also of the consequences of forgoing it. It is only through an awareness of these consequences that there can be any assurance of real understanding and intelligent exercise of the privilege." 384 U.S. 436 , at 469.

107384 U.S. 719 (1966).

$108 \mathrm{Id}$. at $729-30$.

109 Von Moltke v. Gillies, 332 U.S. 708, $723-4$ (1948).

110 Escobedo v. Illinois, 378 U.S. 478 (1964).

111 See, e.g., United States ex rel. Kern v. Maroney, 275 F. Supp. 435 (W.D. Pa. 1967), where the police did not know what the ultimate charges against the accused would be. 


\section{Multiple Interrogation Sessions}

The common police practice of conducting interrogation "sessions" interspersed with periods of confinement raises two further issues that are closely related to the employment of deceptive interrogation tactics and the necessity for police to provide a suspect with more information than the initial warnings. Police interrogators sometimes resort to multiple sessions when new information is discovered after an initial session or when it appears likely that alternating periods of interrogation and confinement will erode a suspect's powers of resistance. Some lower courts have considered whether the Miranda waiver rules require police interrogators to repeat the initial admonition of rights before all subsequent sessions. A few courts have confronted the separate problem of determining whether and under what conditions interrogation may be resumed by the police after an initial interrogation is terminated by a suspect's claim of the right to silence, unaccompanied by a specific request for counsel.

1. The Need for Repeated Warnings. Several lower courts have held that if the Miranda warnings are administered at an initial interrogation session, the police need not repeat the warnings prior to each subsequent session, ${ }^{112}$ even when the sessions are days apart. ${ }^{113}$ These decisions usually rest on the ground that "to adopt an automatic second warning system would be to add a perfunctory ritual to police practices rather than providing the meaningful set of procedural safeguards envisioned by Miranda."114

The "perfunctory ritual" rationale is not without its difficulties. In some situations the gains from a second warning system may greatly outweigh whatever losses ensue from the "ritual" of repeated warnings and waiver. Additional warnings become increasingly necessary as the time between the initial warnings and the subsequent interrogation session increases. ${ }^{115}$ Initial warnings will rarely be sufficient to

112 See, e.g., Miller v. United States, 396 F.2d 492, 496 (8th Cir. 1968); Tucker v. United States, 375 F.2d 365 (8th Cir. 1967), cert. denied, 389 U.S. 888 (1967); People v. Hill, 39 Ill. 2d 125, 233 N.E.2d 367 (1968).

113 See, e.g., Maguire v. United States, 396 F.2d 327 (9th Cir. 1968) (warnings 3 days earlier held sufficient); State v. Magee, 52 N.J. 352, 245 A.2d 339 (1968) (warnings 21/2 days earlier held sufficient).

114 People v. Hill, 39 Ill. 2d 125, 233 N.E.2d 367, 371 (1968).

115 Conversely, repeated warnings may not be necessary when a subsequent interrogation session is conducted only a day after an initial warning. See Sossamon v. State, Ark. - 432 S.W.2d 469 (1968) (repetition of Miranda warnings held unnecessary where the second interrogation followed the first by one day); People v. Sievers, $255 \mathrm{Cal}$. App. $2 \mathrm{~d}$ 34, 62 Cal. Rptr. 841 (Ct. App. 1967) (renewed warnings held unnecessary where second interrogation occurred the day after the initial interrogation, which was preceded by adequate warnings). 
overcome the pressures of police interrogations which occur several days later, possibly with different questioners and in a different setting. ${ }^{116}$ Miranda specifically states that the required warnings are designed not only to advise the suspect of his rights, but also to ensure that he is aware of his interrogator's willingness to recognize his rights should he choose to exercise them. ${ }^{117}$ If the right to terminate questioning at any time after interrogation has begun is to be a meaningful choice for a suspect, he should have a continuing awareness of his rights and of his interrogator's willingness to respect his rights. Without repeated warnings of rights and renewed offers of the opporunity to exercise them, police may exploit an initial waiver by obtaining information from a suspect, conducting further investigations, and then returning to confront the suspect with new evidence and a more searching interrogation, without affording him a genuine opportunity to exercise his rights. ${ }^{118}$

2. The Effects of an Initial Claim of Rights or Termination of Interrogation on a Subsequent Waiver. Frequently, a suspect will claim his rights or cut off questioning at an initial interrogation, only to make an apparently valid waiver and subsequent statement at some later time.119 Miranda provides slight guidance for lower courts attempting to assess the validity of the ultimate waiver. Under Miranda if a suspect in custody asks for a lawyer, "the interrogation must cease until an attorney is present. At that time, the individual must have an opportunity to confer with the attorney and to have him present during any subsequent questioning." 120 The Court was less clear about an initial claim of the privilege or termination of interrogation unaccompanied by a specific request for counsel. If the suspect indicates "in any manner" at any time during the interrogation that he wishes to remain silent, Miranda directs the police to stop questioning him.121 The Court did not indicate, however, whether the presence of counsel is necessary if the police resume interrogation, or whether a higher

116 See Charles v. State, 424 S.W.2d 909, 916 (Tex. Ct. Crim. App. 1967) (Onion, J., dissenting).

117384 U.S. at 468.

118 It should be noted that repeated warnings are not demanded by the Supreme Court's guideline that a suspect's statement should "closely follow" a waiver of rights. 384 U.S. at 475. Subject to the malleable prohibition against "lengthy interrogation," it would seem permissible for police under the present rules to administer an initial warning of rights, interrogate the suspect at later sessions without giving any warnings, and then obtain a waiver "closely followed" by a confession.

119 See, e.g., Wilson v. United States, 398 F.2d 331 (5th Cir. 1968).

120384 U.S. at 474.

121 Id. at $473-4$. 
standard of waiver is required for the admissibility of any subsequent statement.

The California Supreme Court has held that the presence of counsel at subsequent interrogations is automatically invoked by a claim of the right to silence. In People v. Fioritto ${ }^{122}$ the accused refused to sign a written waiver form after being admonished of his Miranda rights. Police interrogators later confronted him with two juvenile accomplices who had confessed and implicated him in a burglary, and repeated the Miranda warnings, inquiring anew whether Fioritto would like to sign the waiver and confess. The California Supreme Court, refusing to uphold the ensuing waiver, excluded Fioritto's subsequent confession from evidence. Emphasizing that its decision furthered the goal of providing concrete rules that would "liberate courts insofar as possible from the difficult and troublesome necessity of adjudicating in each case whether coercive influences, psychological or physical, had been employed to secure admissions or confession," 123 the court made it clear that police may not initiate renewed interrogation after a suspect's claim of the right to silence if counsel is not present. ${ }^{124}$

The California rule furthers the policy against interrogating a suspect against his will ${ }^{125}$ - a concern implicit in Miranda's holding that questioning must be stopped whenever the suspect so requests-but Fioritto appears to represent a minority position. A lack of enthusiasm for the policies underlying Miranda seems to be reflected in the holding of several courts that a claim of the right to silence, of itself, does

12268 Cal. 2d 714, 441 P.2d 625, 68 Cal. Rptr. 817 (1968).

123 Id. at 717,441 P.2d at 626,68 Cal. Rptr. at 818.

124 "By his refusal to waive his constitutional rights initially, defendant indicated that he intended to assert his rights-the privilege had been once invoked-and all further attempts at police interrogation should have ceased. Although the confrontation of defendant with his two juvenile accomplices who had confessed injected a new factor into the questioning, the didactic language of the United States Supreme Court shows no disposition to permit subsequent interrogation in the absence of counsel even if authorities believe there has been a change of circumstances. Thus we have no alternative but to hold that the confession thereafter secured constituted inadmissible evidence at trial." $I d$. at 719 , 441 P.2d at 627, 68 Cal. Rptr. at 819; see People v. Hamilton, —— Cal. App. 2d —, 74 Cal. Rptr. 29 (1968).

125 The Fioritto court carefully excluded from its holding those cases in which renewed questioning is initiated by the suspect. See $i d$. at 719,441 P.2d at 628,68 Cal. Rptr. at 820 . Although an earlier California decision, People v. Tomita, _- Cal. App. 2d —, 66 Cal. Rptr. 739 (Ct. App. 1968), seemed to suggest that lower standards for waiver would apply to interrogations initiated by a suspect after an initial claim of rights, the California courts have not adopted this analysis. At present the California courts dealing with suspect-initiated interrogations distinguish between "passive" or "neutral" police questioning, which is permissible without a showing of waiver, from more active police questioning, which must be preceded by an effective waiver of Miranda rights. See, e.g., People v. Matthews, 264 Cal. App. 2d 630, 一, 70 Cal. Rptr. 756, 764 (Ct. App. 1968); People v. Ireland, 264 Cal. App. 2d 319, 一, 70 Cal. Rptr. 381, 386 (Ct. App. 1968). 
not automatically invoke a suspect's right to the presence of counsel at subsequent interrogations. ${ }^{126}$ Similarly, other courts have held that a termination of questioning by a suspect who does not specifically request counsel does not bar all further questioning initiated by police in the absence of counsel, but merely requires the police to postpone questioning for a "reasonable length of time."127

Even when police initiate renewed interrogation on the same day that the suspect has terminated questioning by claiming his right to silence, the lower courts have sometimes upheld the validity of the ultimate waiver. In Jennings $v$. United States ${ }^{128}$ the defendant was taken to a local police station after being arrested for transporting a stolen car in interstate commerce. The accused, who apparently waived his rights orally after receiving the Miranda warnings, answered a few questions too rapidly for a local interrogating officer to write down his responses, and then terminated the interrogation by claiming his right to silence. In less than an hour an FBI agent arrived at the police station and resumed the interrogation after repeating the warnings. At the second interrogation session, the accused signed a written waiver form and gave a signed, written statement that implicated him in the crime, despite its apparently exculpatory tone. The Fifth Circuit, noting that the FBI agent was unaware of the suspect's earlier claim of the right to silence, upheld the waiver and affirmed the conviction. The court emphasized that adequate warnings preceded both interrogations and that Jennings "found out that immediately upon expressing an unwillingness to proceed the interrogation would promptly stop." 129 It would seem, however, that the suspect found by "claiming" his rights that he could not terminate interrogation but could only postpone police questioning for a short time. The result in Jennings disregards the fact that Miranda's procedural safeguards were clearly intended to accomplish purposes beyond the proscription of intentional police abuses, and ignores the Supreme Court's concern with the impact of questioning on the accused.

126 See, e.g., State v. Godfrey, 182 Neb. 451, 155 N.W.2d 438, cert. denied, 392 U.S. 937 (1968).

127 See, e.g., State v. Bishop, 272 N.C. 283, 158 S.E.2d 511 (1968) (interrogation resumed the next day). Accord: the Miranda dissent of Justice Clark, 384 U.S. at 500.

128391 F.2d 512 (5th Cir. 1968). See also People v. Lewis, 262 Cal. App. 2d 622, 68 Cal. Rptr. 790 (1968), where the suspect's waiver was apparently upheld on the grounds that the police interrogator obtaining the waiver was unaware that the suspect had claimed his right to counsel at an earlier interrogation the day before. The Lewis decision, which preceded and appears to have been overruled by the California Supreme Court's decision in People v. Fioritto, $68 \mathrm{Cal}$. 2d 753, 441 P.2d 625, $68 \mathrm{Cal}$. Rptr. 817 (1968), would seem to be in direct conflict with the mandates of the Miranda Court. See 384 U.S. at 474 .

129391 F.2d at 516. 
It could be argued that the decisions permitting a resumption of interrogation in the absence of counsel after a suspect's claim of the right to silence are not inconsistent with the Supreme Court's goal of promoting a "free and informed" choice of whether or not to remain silent and whether or not to request counsel. Some suspects terminating interrogation may desire neither representation by counsel nor a complete cessation of questioning. The state's interest in interrogation as a means of detecting the guilty, the argument would proceed, demands that this possibility not be foreclosed in the absence of more concrete indications of the suspect's intentions at the time he asserts his rights.

This argument seems tenuous, at best. In most cases, permitting a resumption of interrogation in the absence of counsel sanctions interrogating a suspect against his will, a practice which may be offensive in itself. ${ }^{130}$ Even interrogations resumed after a "reasonable length of time" may have the coercive effect of wearing down a suspect's powers of resistance and browbeating him into a waiver. ${ }^{131}$ The Supreme Court's directives in Miranda do not specifically require a prophylactic rule like that adopted by the California Supreme Court, but the Court's concern with protecting the suspect from involuntary questioning and the inherent dangers of coercion in such questioning strongly imply that higher standards for waiver should apply when renewed interrogation is initiated by the police.

A recent decision of the United States District Court for Montana, United States $v$. Bird,,$^{132}$ indicates that a suspect's initial claim of the right to silence may impose higher standards for a subsequent waiver. The suspect in Bird terminated questioning by local officers by stating that she did not want to "talk anymore." She was then questioned "as a witness" by an FBI agent who did not know of her prior claim of rights. After receiving renewed warnings, the suspect refused to sign a written waiver form presented by the agent. However, when the

130 One of the fundamental policies underlying the privilege is the concern to guard against indiscriminate and unwarranted police interference with individual privacy by guaranteeing a "right to a private enclave" where an individual may "lead a private life." See 384 U.S. at 460 . Thus in Tehan v. United States ex rel. Shott, 382 U.S. 406, 414-16 (1966), the Court emphasized the role of the privilege in protecting the "right . . . to be let alone."

131 One court allowing resumption of questioning in the absence of counsel after a "reasonable time" conceded in dictum that the right to terminate questioning appears to bar any waiver obtained by police who return a suspect to his cell after an initial claim of the right to silence and then periodically bring him out to ask him for a waiver, repeating the process until one is obtained. State v. Godfrey, 182 Neb. 451, 456, 155 N.W.2d 438, 441, cert. denied, 392 .S. 937 (1968).

1324 Crim. L. Rep. 2303 (D. Mont. 1968). 
agent asked her if she wanted to talk without an attorney anyway, she agreed. The court assumed that the suspect's statements were not barred solely by her initial claim of the right to silence, but held that the prosecution failed to carry its "heavy burden" of proof to establish a waiver in view of the suspect's earlier refusal to speak. ${ }^{133}$

Few decisions, however, have imposed a higher standard for waiver after an initial claim of the right to silence. Several courts have held that it is permissible for police interrogators to inform the suspect truthfully of new circumstances which may induce a waiver and statement in the absence of counsel. ${ }^{134}$ The rule emerging from these decisions is consistent with a policy of promoting an informed choice on the part of the suspect, but it appears to increase the danger that police interrogators will attempt to pry a waiver from an unwilling or vacillating suspect by screening the information that reaches him or by exaggerating the significance of new information. Even in the absence of deliberate police distortion, the suspect, unaided by counsel, will usually lack the requisite background to evaluate the significance of the facts imparted to him by the police.

The flexible approach of United States $v$. Bird may be a desirable way of reviewing these "new information" cases. Unlike the prophylactic rule of Fioritto, this approach does not have the disadvantage of frustrating good faith police interrogation as well as misleading and abusive tactics. The California rule prohibiting all interrogation in the absence of counsel, even when the police have new information to impart to the suspect, seems incongruous if the police are free to confront the suspect with any evidence against him prior to a claim of the right to silence. However, the danger of coercion in renewing interrogation after a suspect has claimed his right to silence or in confronting him with new evidence after he has been in confinement suggests that a higher standard for waiver should prevail when the police induce a suspect to "change his mind" and waive his rights.

133 Several additional circumstances supported the result in Bird. After the suspect refused to sign a written waiver form, the agent's question as to whether she would like to talk without a lawyer anyway seems to have been designed to extract a waiver by minimizing its significance. In addition, the suspect had special weaknesses which might have impaired her ability to resist coercion. She was an Indian with an eighth grade education who was described as "drunk" at 1:00 AM on the morning of the interrogation. The interrogation was conducted thirteen miles from her home; apparently, she had no sleep prior to the first session, which began at 7:00 AM. She testified at trial that she "thought maybe I had to" let the police question her.

134 See, e.g., State v. Godfrey, 182 Neb. 451, 155 N.W.2d 438, cert. denied, 392 U.S. 937 (1968); State v. Vangen, - Wash. 2d -, 433 P.2d 691 (1967). But see People v. Fioritto, 68 Cal. 2d 758, 441 P.2d 625, 68 Cal. Rptr. 817 (1968). 


\section{The Suspect's Powers of Resistance}

The waiver issues raised in the preceding sections come sharply into focus when police seek waivers from suspects whose personal weaknesses render them especially susceptible to manipulation or intimidation. ${ }^{135}$ Such individuals, who most need the safeguard of counsel's presence, are the very persons most likely to waive their rights.

Courts assessing the validity of a waiver often seem to utilize the traditional "voluntariness" approach of weighing "the circumstances of pressure against the powers of resistance of the person confessing. What would be overpowering to the weak of will might be utterly ineffective against an experienced criminal."136 The courts have continued to weigh the particular suspect's intelligence, education, and emotional stability, but the Miranda waiver rules provide little guidance for determining the emphasis which should now be given to these circumstances. While the criminal background of a suspect continues to be probative of increased powers of resistance to police trickery and intimidation, ${ }^{137}$ Miranda apparently has not yet altered the rule that youth alone does not render a confession inadmissible. ${ }^{138}$ Similarly, Miranda seems to have had little effect on the traditional rule that intoxication will not render a confession inadmissible unless the suspect's drunken condition amounts to "mania."138a In addition, some courts

135 The Court in Miranda evinced a particular concern to safeguard the legal rights of such suspects. "The potentiality for compulsion is forcefully apparent, for example, in Miranda, where the indigent Mexican defendant was a seriously disturbed individual with pronounced sexual fantasies, and in Stewart, in which the defendant was an indigent Los Angeles Negro who had dropped out of school in the sixth grade." 384 U.S. at 457.

136 Stein v. New York, 346 U.S. 156, 185 (1953) (Jackson, J.).

137 See, e.g., State v. Magee, 52 N.J. 352, 245 A.2d 339 (1968) (accused's experience with criminal and civil courts and processes demonstrated that his waiver of counsel was a deliberate and understanding choice); State v. Collins, - Wash. 2d -, 446 P.2d 325 (1968) (accused's criminal record of six felony convictions was evidence that he had not been deceived by an interrogating officer's alleged assurance that their conversation was "strictly off the record"); State v. Vangen, - Wash. 2d - 433 P.2d 691 (1967) (accused's criminal background indicated that his waiver and confession were not the result of his illegal arrest and detention).

138 See, e.g., Rivers v. United States, 400 F.2d 935 (5th Cir. 1968) (18); West v. United States, 399 F.2d 467 (5th Cir. 1968) (16); People v. Hill, 39 IIl. 2d 125, 233 N.E.2d 367, cert. denied, 392 U.S. 936 (1968) (17); People v. Watts, - Ill. App. 2d -, 241 N.E.2d 463 (1968) (20); Miller v. State, - Md. App. -, 247 A.2d 530 (Ct. App. 1968) (16); State v. Wiggins, 4 Md. App. 95, 241 A.2d 424 (1968) (15). One commentator predicted that under Miranda no waiver from a "juvenile" under 16 (as opposed to a "youth" between 16 and 2I) could conceivably be found unless counsel or a parent was present during the interrogation. N. Sobel, The New Confession Standards-Miranda v. Arizona 11 (1966).

138a See State v. Manuel, - La. -, 217 So. 2d 369, 371 (1968), where the Louisiana Supreme Court found an "intelligent" waiver by a suspect who claimed he was drugged, stating that "[t]o render a confession inadmissible, drug or alcohol intoxication must be of such a degree as to negate the defendant's comprehension and render him unconscious 
continue to hold that a confession will not be barred simply because the suspect is severely and obviously emotionally upset during interrogation. ${ }^{138 b}$ Thus, after the Miranda warnings have been administered, many lower courts seem to apply old standards of "voluntariness" to weigh the significance of personal weaknesses of the suspect.

The principal impact of the Miranda waiver rules on the traditional standards for evaluating the personal characteristics of a suspect stems from the Court's mandate that a waiver be "intelligently" made. The concept of an "intelligent" waiver, however, is paradoxical. In People v. $L u x^{139}$ a New York court noted that the unanimous opinion of criminal lawyers is that "a client being interrogated [should] refuse to waive anything pending a dispassionate evaluation of the strength of the enemy. If an intelligent specialist would so advise, then anyone who does waive is presumably acting unintelligently."140 Rather than eliminate all possibility of waiver, the New York court decided that the concept of an intelligent waiver in the absence of an attorney is an "amiable fiction." Focusing its inquiry on the intelligence of the individual waiving the right rather than the intelligence of the waiver decision itself, the New York court concluded that the requisite intelligence required by Miranda is "the intelligence demonstrated to a reasonable degree by that panacea of the law-the reasonable man."141

The New York court's reasonable man test appears to permit waivers made with less than full appreciation of the tactical advantages that may be gained by silence at interrogation-such as bargaining for a reduced sentence or lesser charges in return for a guilty plea. This seems consistent with the fact that Miranda does not require the actual presence of counsel at interrogation. At the same time, a reasonable man test would exclude waivers made by suspects with diminished intelligence or marked psychological weaknesses. For such suspects it is extremely unlikely that a warning of rights can provide "assurance of real understanding and intelligent exercise of the privilege of silence" or overcome the compulsions of the interrogation atmosphere.

of what he is saying. If a defendant understands the statements directed to him and knows what he is saying, the confession is admissible."

Other courts seem more reluctant to specify standards. See State v. Fisk, — Idaho -, 448 P.2d 768 (1968), where the Idaho Supreme Court simply affirmed the trial court's ruling that "although defendant had been drinking, he was sober enough to, and did, voluntarily, intelligently and knowingly waive" his Miranda rights. A blood test established that at the time of his waiver and confession the defendant had an alcohol blood content sufficient to establish a presumption of drunkenness under the Idaho drunk driving statute.

138b See, e.g., Estes v. State, - Ga. -, 164 S.E.2d 108 (1968).

13956 Misc. 2d 561, 289 N.Y.S.2d 66 (Suffolk County Ct. 1967).

140 Id. at 563, 289 N.Y.S.2d at 69.

141 Id. at 564,289 N.Y.S.2d at 70. 
Thus the Lux court found that while the defendant's waiver was made knowingly and willingly, it was not made "intelligently" because the suspect had "a low level of understanding of semantics" and "an unusual psychological desire to give pleasing answers to his interrogators," and had been in police custody for three to three and one-half hours before confessing. ${ }^{142}$

Most lower courts, like the New York court, have inquired into the intelligence of the individual rather than the intelligence of his waiver, but the courts have differed considerably as to the requisite intelligence required by Miranda for a valid waiver. In People v. Randolph,,$^{143}$ a New York court employed the $L u x$ reasonable man test to invalidate a waiver by a practically illiterate suspect who had an I.Q. of 68 and less than a sixth grade education. In Elrod $v$. State, ${ }^{144}$ on the other hand, the Alabama Supreme Court upheld a waiver of Miranda rights by an apparently feebleminded illiterate with a second grade education, whose testimony revealed that he had never heard of the United States Constitution. ${ }^{145}$ The Randolph decision interpreted the test of an "intelligent" waiver to require a full understanding not only of the warnings but also of the consequences of foregoing one's rights. ${ }^{146}$ In State v. McKnight, ${ }^{147}$ however, the New Jersey Supreme Court stated that a suspect must understand only that he has the right to remain silent and that a waiver is no less "voluntary, knowing and intelligent" if he misunderstands the meaning of the Miranda warnings, as by failing to appreciate that oral as well as written statements can be admitted in evidence against him. ${ }^{148}$

These cases illustrate the elasticity of Miranda's requirement of an "intelligent" waiver. But some of the lower court decisions seem inconsistent with the Supreme Court's analysis of the function the required warnings are to serve. It is unlikely that the suspect in Elrod was capable of appreciating the warnings sufficiently to make informed decisions to remain silent and to request counsel. The rule announced

$142 I d$.

143 - Misc. 2d -, 294 N.Y.S.2d 933 (Genessee County Ct. 1968).

144231 Ala. 331, 202 So. 2d 539 (1967).

145 Compare the remark of one commentator, "[t]hus illiteracy, feeblemindedness or a history of mental illness, if externally established, will never support a finding of either understanding of the warning or intelligent waiver." N. SOBEL, THE NEw CONEEsSION STANDARDS-MIRANDA v. ARIzONa 13 (1966).

146 - Misc. 2d at -, 294 N.X.S.2d at 936. See People v. Dumas, 51 Misc. 2d 929, 274 N.Y.S.2d 764 (Sup. Ct. 1966).

14752 N.J. 35, 243 A.2d 240 (1968).

$148 \mathrm{Id}$. at -, $243 \mathrm{~A} .2 \mathrm{~d}$ at 25I. See $i d$. at $\rightarrow, 243 \mathrm{A.2d}$ at 250-1: "[I]t is consonant with good morals and the Constitution, to exploit a criminal's ignorance or stupidity in the detectional process." 
in McKnight appears to be a more forthright emasculation of Miranda. One of the minimum purposes of the required warnings was to ensure that a suspect is made aware of the consequences of foregoing his right to silence, at least to the extent that he appreciates that his statements can be used in evidence against him. ${ }^{149}$ Although full knowledge of the consequences of relinquishing the right to silence may be impossible in the absence of counsel, a minimum requisite to any "knowing" waiver would seem to be an awareness by the suspect that his oral statements are just as binding as those in writing.

The reluctance of the McKnight and Elrod courts to inquire into the suspect's understanding of his Miranda rights may be caused in part by the difficulties of determining a suspect's mental capacity to waive his rights. As under the "voluntariness" standard, many post-Miranda courts have inquired into the psychological responses of the particular suspect to police pressures during detention and interrogation. Some decisions have attempted to lessen the difficulties of this inquiry ${ }^{150}$ by emphasizing the visible outward appearances of the suspect and the knowledge of police interrogators of the suspect's mental condition at the time a waiver and confession were made. In People v. Golwitzer, ${ }^{151}$ a New York court emphasized that indications of the defendant's mental condition and background were known to police at the time of interrogation, and refused to uphold an express oral waiver by a suspect with a history of emotional instability. A similar approach was employed in State $v$. Bower ${ }^{152}$ to affirm a conviction over the appellant's contention that at the time of his waiver he was suffering from a narcotic hangover which rendered him temporarily mentally incompetent. The court stressed the testimony of police interrogators that the suspect appeared normal, physically and emotionally, and

\footnotetext{
149 "It is only" through an awareness of these consequences that there can be any assurance of real understanding and intelligent exercise of the privilege." 384 U.S. at 469.

150 One recent survey of the social science literature states that a suspect's capacity to resist coercive influences in custodial police interrogation is strengthened by self-confidence, self-assertiveness, prior exposure to interrogations, and a "high need for achievement and an orientation of attention primarily toward the content of what is perceived rather than toward its source (persons)." Driver, Confessions and the Social Psychology of Coercion, 82 HARv. L. REv. 42, 48-9. "Low status persons-those who have never enjoyed a secure or rewarding social position-are likely to be the most vulnerable of all to indoctrination, and persons with 'strong unconscious, self-punitive tendencies ... not only (tend) to confess more easily but even to confess to crimes never actually committed.' "Id. at 48. Although a suspect's social status and prior criminality may be readily established at trial, formidable problems of proof would have to be overcome to establish the suspect's psychological characteristics.
}

15152 Misc. 2d 925, 277 N.Y.S.2d 209 (Erie County Ct. 1966).

152 - Wash. 2d -, 440 P.2d 167 (1968). 
that they had noticed nothing to indicate that he was under the influence of drugs at the time of confession..$^{153}$

By emphasizing the suspect's visible outward appearances the Golwitzer and Bower courts avoided the practical difficulties inherent in any direct attempt to ascertain the suspect's actual state of mind at the time of a challenged waiver of rights. These difficulties may be particularly acute in cases like Bower where the suspect claims that his mental facilities were only temporarily impaired. In such cases a test which seeks to ascertain the suspect's actual state of mind at the time of a waiver would of necessity depend solely on the testimony of the accused, since he alone is in a position to testify as to his actual state of mind. The dangers of perjured or distorted testimony attaching to such a test might be prohibitively high. On the other hand, reliance upon visible outward appearances minimizes the Miranda Court's concern for the impact of custodial questioning on the accused. A test emphasizing the visible indication of a suspect's mental state appears to deter the deliberate exploitation by police of obviously incompetent suspects, but paradoxically such a test is almost totally dependent upon police testimony. A court attaching importance to outward appearances might illogically admit waivers by suspects who appear normal but who in fact do not have sufficient mental capacity to make a valid waiver, while excluding waivers by suspects whose mental capacity is visibly impaired at the time of confession, but who in fact have suffcient mental presence to effect a voluntary, knowing and intelligent waiver. ${ }^{154}$

Judicial inquiry into a suspect's actual mental capacity seems to be an unavoidable necessity, since many suspects are particularly susceptible to manipulation. The difficulties courts experience when attempting to ascertain a suspect's understanding of his Miranda rights and his willingness to waive those rights can be substantially reduced,

153 Id. at,$- 440 \mathrm{P} .2 \mathrm{~d}$ at 173.

154 See Note, Intoxicated Confessions: $A$ New Haven in Miranda?, 20 STAN. L. REv. 1269 (1968), for a discussion of some of the problems inherent in "objective" and "subjective" tests of a suspect's mental capacity.

The search for easily administered criteria by which to gauge the suspect's state of mind at the time of the challenged waiver is illustrated by the recent Montana case, State v. Lucero, - Mont. -, 445 P.2d 731 (1968). In Lucero, interrogating officers testified at trial that the defendant at the time of her arrest was "under the influence" of alcohol and "didn't seem to be aware of the happenings," but that she "regained her composure" prior to later warnings and questioning. The defendant testified that she did not remember being given the Miranda warnings or waiving her rights, nor did she remember the subsequent questioning and statement. Affirming the conviction, the Montana Supreme Court stressed that the content of the defendant's apparently exculpatory statement indicated that "her mental facilities were operating in high gear at the time of the interrogation." Id. at,- 445 P.2d at 737. 
however, by requiring the police to take reasonable precautions to ensure that a waiver is "voluntarily, knowingly and intelligently" made. Explaining the meaning and significance of the Miranda warnings and waiver, repeating the warnings at widely separated interrogation sessions, notifying the suspect of the crime he is suspected of having committed, and obtaining an express waiver of rights before any interrogation should compensate for the low mental capacity of many suspects. As the foregoing cases illustrate, many lower courts do not require these precautions to be taken before a waiver can be obtained from suspects with particular deficiencies. In the absence of more specific Supreme Court mandates the lower courts retain considerable autonomy in assessing the significance of a suspect's personal weaknesses. It appears that many courts have concluded that the suspect's porvers of resistance should be given no more consideration than under the traditional voluntary-confessions standard.

\section{Conclusion}

MIRANDA. If by your art, my dearest father, you have Put the wild waters in this roar, allay them..$^{155}$

Miranda was prompted in part by the conflicting lower court confession standards which emerged in response to Escobedo v. Illinois. But the ambiguities of Miranda, like those of Escobedo before it, have resulted in uneven implementation of the Supreme Court's goals in the lower courts. Many courts, perhaps because of their hostility to limitations on police interrogations, have managed to equate the Court's requirement of a "voluntary, knowing and intelligent" waiver with the pre-Miranda "voluntariness" test. These courts have assessed the totality of circumstances surrounding a waiver in much the same way they traditionally weighed the circumstances surrounding the confession itself. They have paid little heed to the Supreme Court's requirement that a waiver be "knowing and intelligent" as well as "voluntary." In many jurisdictions the Court's new confession standards have been interpreted to require little more than an incantation of four-fold warnings by the police; the degree of free choice required for the admissibility of statements made during interrogation has been little changed. If the Court intended to establish more stringent standards for the admissibility of confessions, and if Miranda's approach to the confessions dilemma is to be retained, more explicit waiver guidelines are needed.

155 W. Shakespeare, The Tempest, Act I, sc. ii, lines 1-2. 